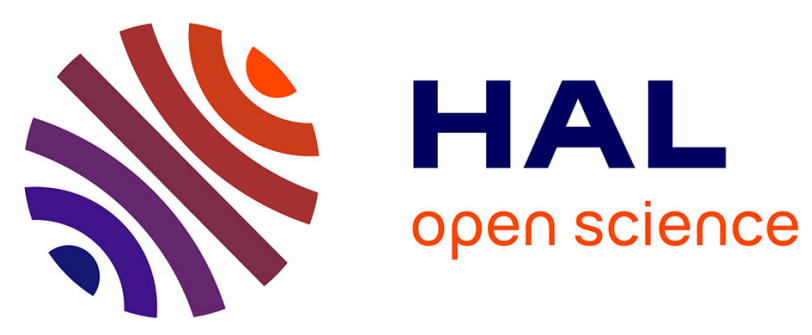

\title{
Tritium in river waters from French Mediterranean catchments: Background levels and variability
}

Loic Ducros, Frédérique Eyrolle, Claire Della Vedova, Sabine Charmasson, Marc Leblanc, Adriano Mayer, Milanka Babic, Christelle Antonelli, David Mourier, Franck Giner

\section{To cite this version:}

Loic Ducros, Frédérique Eyrolle, Claire Della Vedova, Sabine Charmasson, Marc Leblanc, et al.. Tritium in river waters from French Mediterranean catchments: Background levels and variability. Science of the Total Environment, 2018, 612, pp.672-682. 10.1016/j.scitotenv.2017.08.026 . hal02355444

\section{HAL Id: hal-02355444 \\ https://hal.science/hal-02355444}

Submitted on 5 Jun 2021

HAL is a multi-disciplinary open access archive for the deposit and dissemination of scientific research documents, whether they are published or not. The documents may come from teaching and research institutions in France or abroad, or from public or private research centers.
L'archive ouverte pluridisciplinaire HAL, est destinée au dépôt et à la diffusion de documents scientifiques de niveau recherche, publiés ou non, émanant des établissements d'enseignement et de recherche français ou étrangers, des laboratoires publics ou privés.

\section{(ㅇ)(1) $\$$}

Distributed under a Creative Commons Attribution - NonCommercial - NoDerivatives| 4.0 


\title{
Tritium in river waters from French Mediterranean catchments: Background levels and variability
}

Loïc Ducros ${ }^{a}$, Frédérique Eyrolle ${ }^{a}$, Claire Della Vedova ${ }^{a}$, Sabine Charmasson ${ }^{a}$, Marc Leblanc $^{c}$, Adriano Mayer ${ }^{c}$, Milanka Babic ${ }^{c}$, Christelle Antonelli ${ }^{b}$, David Mourier ${ }^{a}$, Franck Giner ${ }^{a}$

a - Institut de Radioprotection et de Sureté Nucléaire (IRSN), PSE-ENV, SRTE/LRTA, BP 3, 13115 Saint-Paul-lez-Durance, France

b - Institut de Radioprotection et de Sureté Nucléaire (IRSN), PSE-ENV, SEREN/LEREN, BP 3, 13115 Saint-Paul-lez-Durance, France

c - Hydrogeology Group, UMR EMMAH, University of Avignon, 84000 Avignon, France

https://doi.org/10.1016/j.scitotenv.2017.08.026

\section{Highlights}

- Tritium contents in river waters are lower than in rain waters.

- Contrarily to rain waters no seasonality is demonstrated for river waters.

- Variation of tritium concentrations in rivers depends on various parameters.

- Tritium inputs by rainfall, altitude, basin surface are the main parameters involved.

- Tritium fluxes delivered to the Mediterranean Sea are estimated.

\begin{abstract}
Tritium background levels in various environmental compartments are deeply needed in particular to assess radiological impact, especially in river systems where most of releases from nuclear facilities are performed. The present study aims to identify the main environmental factors that influence tritium background levels in rivers at the regional scale. 41 samples were collected from 2014 to 2016 along 17 small rivers in the south of France. All were located out of the influence of direct releases from nuclear facilities. Tritiated water (HTO) concentrations measured in water samples ranged from $0.12 \pm 0.11$ to $0.86 \pm 0.15 \mathrm{~Bq} \mathrm{~L}^{-1}$ and HTO concentrations in rains were modelled between 2015 and 2016 over the study period referring to time series acquired from 1963 to 2014 at Thonon-les-Bains monitoring station. The results of tritium concentrations in rivers studied present a significant variability and are more than twice lower than forecasted values in rain. Multiple linear regressions allowed identifying that HTO concentration in rains, watershed area and altitude were the main tested parameters that are linked to the variability of HTO concentrations in the studied rivers. Finally, HTO fluxes delivered to the Mediterranean Sea by French coastal rivers out of influence of nuclear releases
\end{abstract}


were estimated. The results highlight that those account for around 1\% of HTO exported while $99 \%$ are transferred by the nuclearized Rhone River.

Graphical abstract :

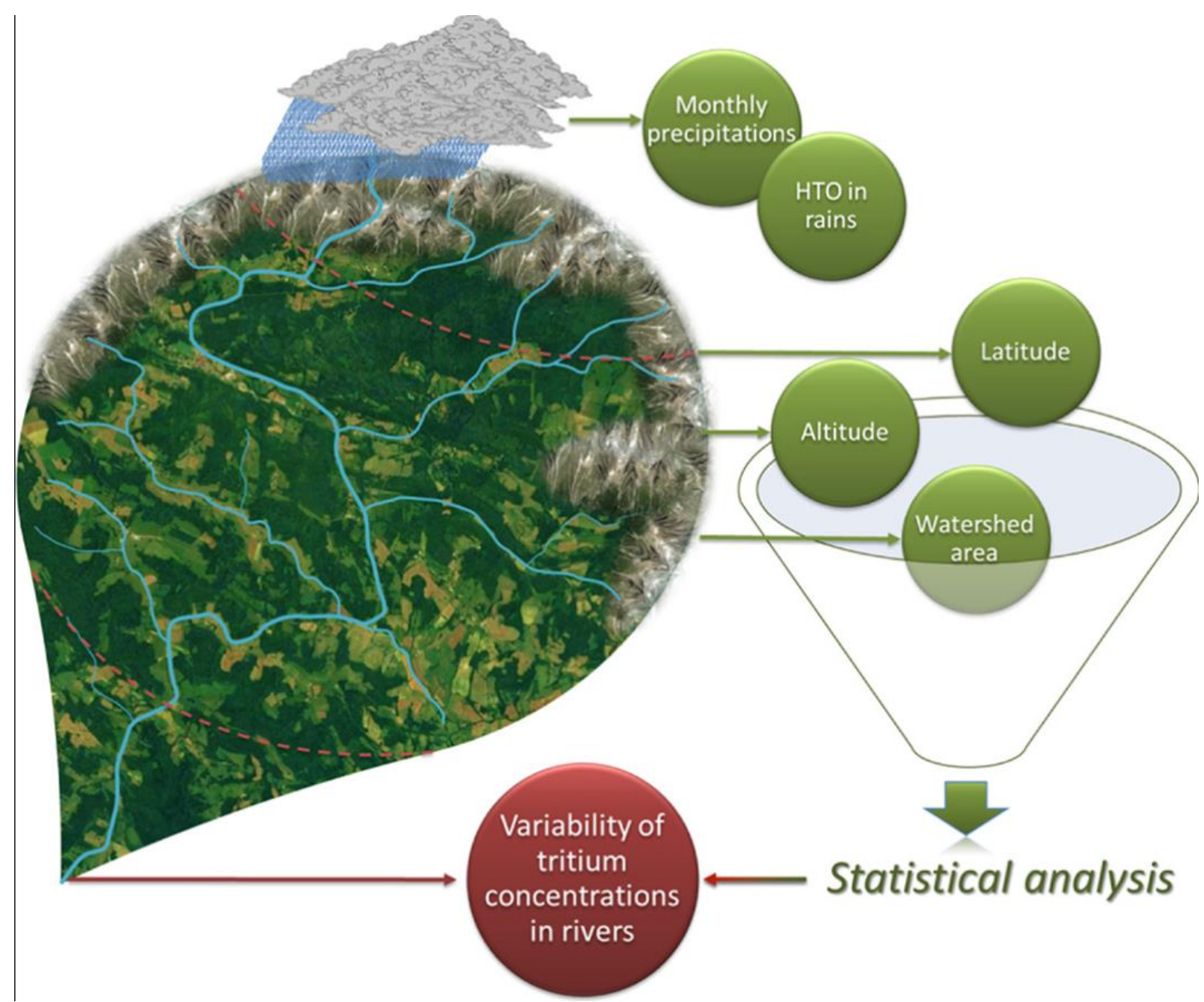

\section{Keywords}

${ }_{3} \mathrm{H}$; River ; HTO ; Rainfalls ; Tritium fluxes

\section{Introduction}

Tritium is the radioactive hydrogen isotope characterized by a half-life of 12.32 years, a low energy beta emitter (average energy of $5.7 \mathrm{keV}$ ) decaying to the stable element ${ }^{3} \mathrm{He}$. Tritium is naturally produced in the environment mainly by nitrogen $\left({ }^{14} \mathrm{~N}\right)$ atoms absorbing neutrons from cosmic rays in the upper atmosphere, a production significantly higher than its telluric production. These natural processes lead to a rather constant amount of $1 \mathrm{EBq}$ at equilibrium at the global scale (Eisenbud et al., 1979, Zerriffi, 1996). Tritium had been also artificially produced since the middle of the last century by the atmospheric nuclear weapon testings from 1945 to 1980, with peaking releases in 1958 and 1962. Explosions from nuclear tests led to tritium emissions in the atmosphere as tritiated hydrogen (HT) and methyl tritium gas 
$\left(\mathrm{CH}_{3} \mathrm{~T}\right)$ that were rapidly oxidized and converted into tritiated water molecules (HTO). Those inputs generated tritium concentrations in rains more than one hundred times above natural levels during the peaking emissions in 1963 (UNSCEAR, 2000).

Among contemporary anthropic sources of tritium, reprocessing plants release most quantities. For example, nuclear discharges of AREVA NC La Hague (France) are about 10 times larger than releases of all French Nuclear Power Plants (NPP) (IRSN, 2009). Currently, tritium is the major radionuclide, with ${ }^{14} \mathrm{C}$, to be released in both liquid and gaseous effluents by Nuclear Power Plants (Gontier and Siclet, 2011). Tritium is additionally released to a lesser extent by tritium production facilities and other plants using tritiated compounds regarding their luminescent properties or for medical research purposes. At the global scale about $0.1 \mathrm{EBq}$ per year are released by the nuclear installations (UNSCEAR, 2000); i.e., 10 fold less that the natural production at equilibrium.

Tritium exchanges very quickly with hydrogen or water molecules and is thus extremely mobile and ubiquitous in all compartments of the environment. It is encountered in gaseous forms ( $\left.\mathrm{HT}, \mathrm{CH}_{3} \mathrm{~T}\right)$, liquid form (HTO), as well as associated with naturally-occurring organic compounds (Organically Bound Tritium - OBT), or with man-made organic molecules (Croudace et al., 2012, Krejci and Zeller, 1979) or refractory sub micrometric particles (ElKharbachi et al., 2014). HTO is by far the predominant form in the environment and thus closely follows the whole water cycle and the water mass dynamics. Consequently, it is generally encountered in various components of the hydrosphere including atmosphere, rivers, marine waters, underground waters, interstitial water in soils and sediments and tissue free water within organic compounds.

Tritium was widely used in the field of hydrogeology for its tracing properties enabling to estimate origin, residence time, dynamic, mixing, storage volumes of groundwater and their zone of discharge in surface waters (Gusyev et al., 2016, Mayer et al., 2014, Michel, 1992, Michel, 2004, Mundschenk and Krause, 1991, Ravikumar and Somashekar, 2011, Subbotin et al., 2013). Tritium was also widely used like tracer in the frame of marine studies (Andrie and Merlivat, 1988, Bailly du Bois et al., 2002, Broecker et al., 1986, Bush, 1988, Butzin and Roether, 2004, Göte Östlund, 1994, Göte Östlund et al., 1974). Finally, various studies were performed in order to investigate the radiological impact of tritium releases from nuclear facilities on the environment referring to pre-testing baseline levels (Dinçer and Davis, 1984, Eyrolle-Boyer et al., 2014, Mundschenk and Krause, 1991, Vakulovskii et al., 1978). Tritium behavior and fate were often studied close to military, industrial or nuclear research center areas such as Semipalatinsk Nuclear Test Site (Mitchell et al., 2008, Subbotin et al., 2013), NPP (Ciffroy et al., 2006, Gontier and Siclet, 2011, Kotzer and Workman, 1999, Mundschenk and Krause, 1991, Péron et al., 2016) or more rarely after the Fukushima Dai-ichi NPP accident (Kakiuchi et al., 2012, Matsumoto et al., 2013, Ueda et al., 2015). Some studies contributed to establish long time series for tritium concentrations in various hydrosystems and generally allowed to determine tritium activity in the nearest influenced zone close to those sites, i.e., the amount of anthropogenic tritium at the downstream part of nuclearized rivers (Bondareva and Rubailo, 2016, Ciffroy et al., 2006, Marang et al., 2011, Pujol and Sanchez-Cabeza, 2000, Tomášek and Wilhelmová, 1996, Varlam et al., 2012).

In this context, tritium baseline levels are deeply needed in the various environmental compartments in order to characterize the environmental impact of nuclear releases and to identify potential sources of tritium other than nuclear facility discharges. It is known that tritium baseline (HTO form) in rivers varies according to physical, climatic and geographic 
parameters spreading from regional to global scales within the hydrosphere. Therefore, in order to assess to the variability of tritium concentrations in rivers, water samples were collected among various French Mediterranean catchment located out of the influence of atmospheric and liquid nuclear releases. Statistical approaches were performed in order to identify the most sensitive parameters accounting for the variability of HTO concentrations in rivers. Finally, tritium fluxes delivered from these different rivers to the northwestern part of the Mediterranean Sea were estimated and compared to those calculated for the nuclearized Rhône River.

\section{Materials and methods}

\subsection{Location of sampling areas}

Sampling stations were mainly selected in South-Eastern France, in rivers out of influence of atmospheric or liquid radioactive releases from nuclear facilities in agreement with EyrolleBoyer et al. (2014) (Fig. 1). All nuclear power plants and a reprocessing plant (Marcoule) 
were taken into account in order to avoid any impact of direct atmospheric and liquid releases.

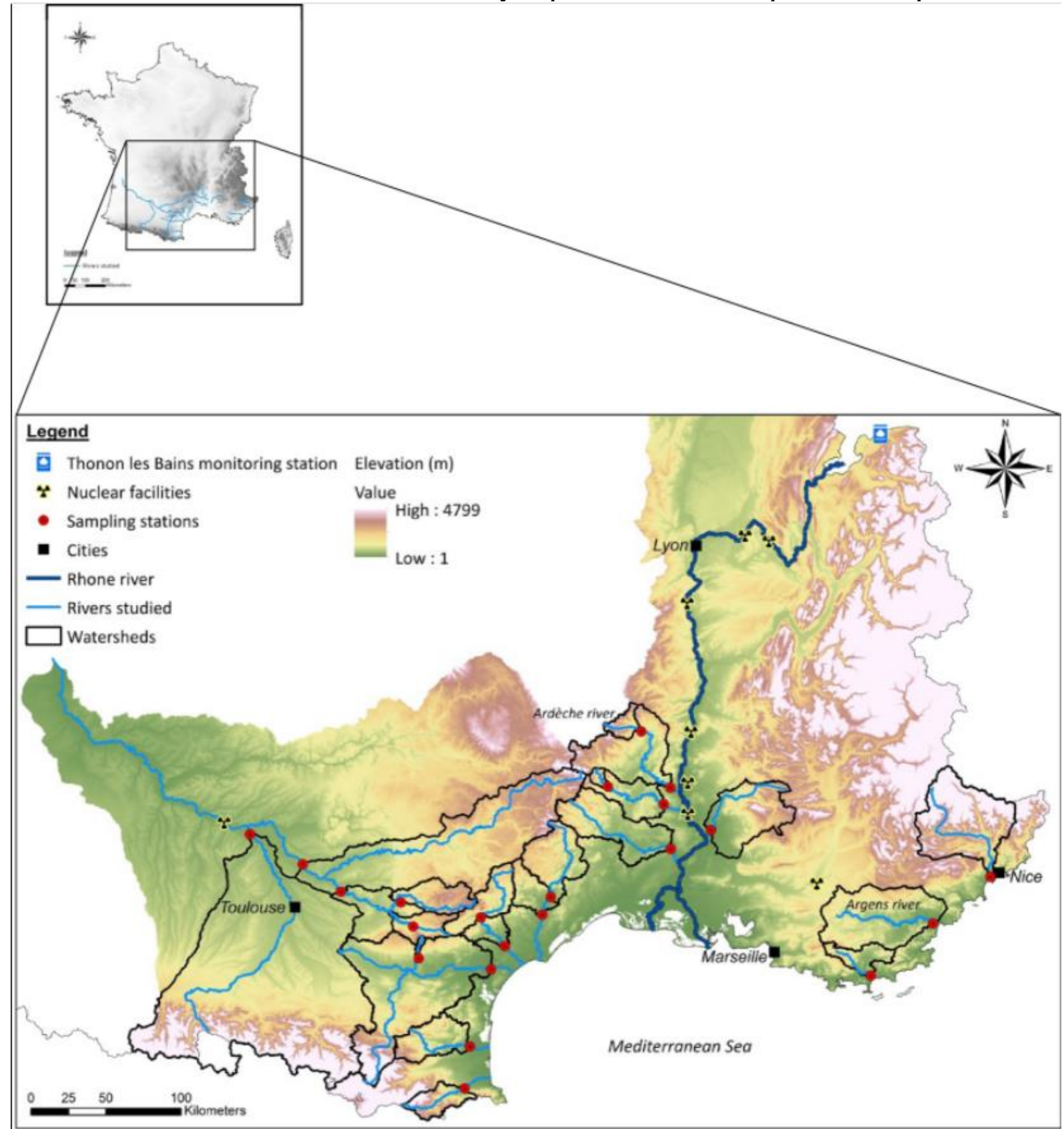

1. Download : Download high-res image (1MB)

2. Download : Download full-size image

Fig. 1. Location of the study area. Sampling stations are represented by red points. Rivers investigated are symbolized in light blue and the Rhône River in dark blue. Watersheds are demarcated by black lines. The background colors show the elevation. (For interpretation of the references to color in this figure legend, the reader is referred to the web version of this article.)

In order to identify these areas, GIS software (ARCGIS) were used to target rivers. Various upstream and downstream stations were selected and sampled to study variations of tritium concentrations in freshwater. 


\subsection{Sampling}

This step was manually carried out using a sampling rod to sample in the center of the river (in the middle of the water column after the depth has been estimated) in order to enhance the representativeness and limit remobilization of particles from bottom sediments and banks. All samples were taken after at least 7 days without rainfalls and flood events. Samples were filtered directly in-situ with GVS® filters $(0.22 \mu \mathrm{m})$. The filtered water was immediately stored in previously dried $\left(40{ }^{\circ} \mathrm{C}\right)$ amber glass vials then stocked in a cooler to the laboratory. Then, samples were packaged in aluminized bags under vacuum in order to avoid any exchange with the surrounding atmosphere and stored at $4{ }^{\circ} \mathrm{C}$ until analysis.

\subsection{Analytical method}

Two analytical methods were used to quantify tritium concentrations in river water samples.

Samples filtered in the field then distilled in laboratory. $70 \mathrm{~mL}$ of water sample with $70 \mathrm{~mL}$ of scintillation cocktail (Ultimagold LLT - PerkinElmer) in a polythene antistatic vial before scintillation counting with Hitachi ALOKA LSC-LB7. The mean uncertainty is equal to $57 \%$.

$500 \mathrm{~mL}$ of water sample distilled then concentrated by electrolytic enrichment during 9 days to obtain an average enrichment factor of 25 . In a second part, added $12 \mathrm{~mL}$ of scintillation cocktail (Ultimagold uLLT - PerkinElmer) with $8 \mathrm{~mL}$ of the sample enriched and neutralized with lead chloride in a polythene antistatic vial before scintillation counting with Tricarb $3180 \mathrm{TR} / \mathrm{SL}$. The mean uncertainty is equal to $7 \%$.

\subsection{Other data sets}

Tritium concentrations in rainfall in Thonon-les-Bains (France) near Geneva (Switzerland) (altitude: $385 \mathrm{~m}$; latitude: $46.3708^{\circ}$ ) (Fig. 1) are produced for the International Atomic Energy Agency (IAEA) and available in the Wiser Data base (Global Network of Isotopes in Precipitation (GNIP)) from 1953 until 2012. Rain water samples measured between 2012 and 2014 were provided by the Laboratory of Hydrogeology of Avignon University (UMR

EMMAH). Tritium concentrations in rainfall after 2014 were established by forecasting. Rainfall intensity and altitude data sets arise from Météo-France and are available on "Publithèque" (https://publitheque.meteo.fr). Hydrological data set for all rivers come from the "Banque HYDRO - MEEDDAT/DGPR/SRNH"

(http://www.hydro.eaufrance.fr/indexd.php).

Surface areas of drainage basins were calculated with GIS software (ARCGIS) and a Digital Elevation Model (DEM).

\subsection{Statistical analysis}

\subsubsection{Modelling rain tritium concentration time series in Thonon-les-Bains (France)}


Monthly tritium concentrations measured in rainwater in Thonon (France) between January 2000 and December 2014 (i.e. 180 measurements) were modelled using autoregressivemoving-average (ARMA) model. The original time series contained 18 missing

measurements. As a seasonal trend was present, missing values were imputed using average between monthly measurement of the previous and following year. For instance June 2005's monthly measurement was imputed using an average of monthly measurement in June 2004 and June 2006.

Since the imputed time series was stationary and contained a seasonal trend, it was modelled using a seasonal ARMA model with a 12 months' period, more precisely a SARMA $(0,1)(1,1)_{12}$. Choices concerning parameters were done visualising the Autocorrelation Function (ACF) and Partial Autocorrelation Function (PACF), and final model selection was done using Akaike information criterion (AIC), as recommended by (Aragon, 2011). This final model was then used to forecast tritium concentration in rains in Thonon-les-Bains in 2015 and 2016. These forecasted concentrations were then used as a predictive variable in a multiple linear regression in order to assess the impact of various parameters onto rivers tritium concentrations.

\subsubsection{Impact assessment of multiple variables on monthly tritium activity exported by rivers}

A multiple linear regression was used in order to assess the impact of different factors onto monthly tritium activity exported by rivers. The explanatory variables were: forecasted monthly tritium activity deposited by rains, drainage area, monthly cumulated precipitations, altitude and latitude at the sampling station in rivers. For this aim we fitted a linear mixed effect model (LMM), where explanatory variables were considered as fixed effect, and monthly tritium activity in rivers as the response variable. Rivers were included as random effect on the intercept, in order to take into account that the measurement performed in the same river would exhibit more similarity that with other rivers. Moreover, we weighted the multiple linear regression according to the inverse of the uncertainty of the rivers tritium concentration, giving weight to more precise response.

Rains and rivers monthly tritium activities, and drainage area were $\log _{10}$ transformed in order to improve the relationships linearity as well as residuals normality and homogeneity. Residuals normality assumption was assessed visually using a "quantile quantile plot", and residuals homogeneity assumption was assessed using a "residuals vs fitted plot". Multicollinearity between explanatory variables was check deriving Variance Inflation Factor (VIF), they all were < 5. Moreover, this absence of multicollinearity is confirmed by a Pearson correlation matrix plot (Fig. 2). Absence of spatial correlation was assessed visually using a bubble plot on residuals (Zuur et al., 2009a), and lack of time correlation was assessed using an Autocorrelation Function plot on residuals too (Zuur et al., 2009b). 


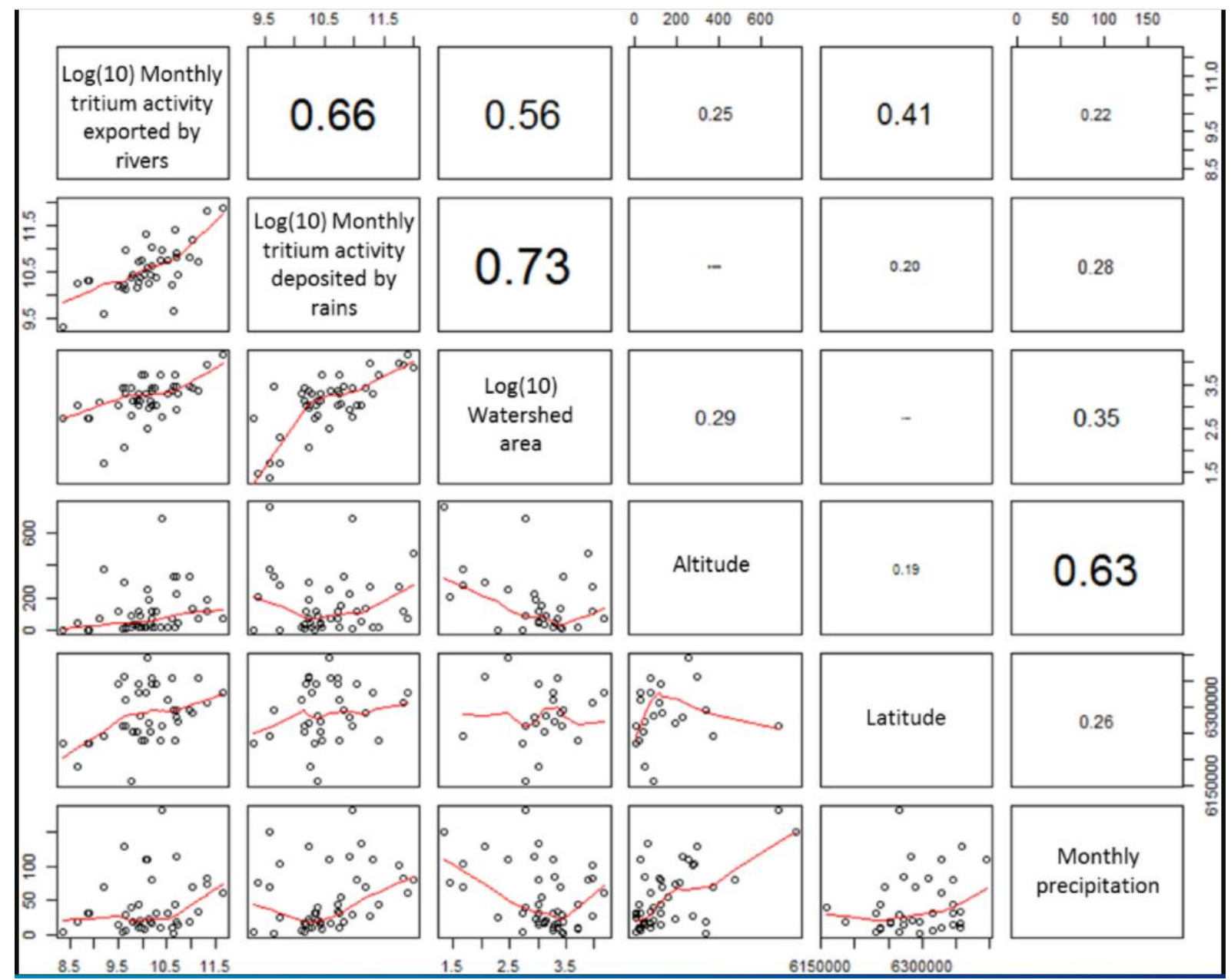

1. Download : Download high-res image (803KB)

2. Download : Download full-size image

Fig. 2. This scatterplot correlation matrix displays the Pearson correlation coefficients between paired explanatory variables: monthly tritium activity deposited by rains, watershed area, altitude, latitude and monthly precipitation at the sampling station in rivers. On the bottom of the diagonal, the bivariate scatter plots with a fitted red line are presented and on the top of the diagonal, the values of the correlations are displayed.

LMM was fitted using REML (Restricted Maximum Likelihood method). The significances were assessed using $t$-test with Satterhwaite approximations to degree of freedom, after adjustment of $\mathrm{p}$-values by single step method because of the multiple comparisons. Significance level was fixed at $5 \%$.

All the analyses were carried out with $\mathrm{R}$ software (R Core Team, 2016) (version 3.3.2) and $\mathrm{R}$ studio environment (R StudioTeam, 2015) (version 0.99.484). Time series modelling was done using Arima function of the forecast package (Hyndman, 2016). This package was also used to forecast rain tritium concentration. LMM were fitted using lmer function of the lme4 package (Bates et al., 2015). p-Values were adjusted using the glht function of multcomp package (

\section{Results and discussion}




\subsection{Reconstruction of tritium concentrations in rains}

Data of tritium concentrations in rains over our sampling period i.e. March 2014 to September 2016 are not available on the Wiser Database of IAEA (GNIP). Therefore tritium

concentrations in rains have been modelled over this period (Fig. 3) during which they varied from $0.59 \mathrm{~Bq} \mathrm{~L}^{-1}$ in the first two months of 2014 to $1.55 \mathrm{~Bq} \mathrm{~L}^{-1}$ in July 2014 in Thonon-lesBains, the nearest sampling station to our study area with close altitude $(385 \mathrm{~m})$ and latitude $\left(46.3708^{\circ}\right)$ values and an important time series of tritium concentrations in rains.

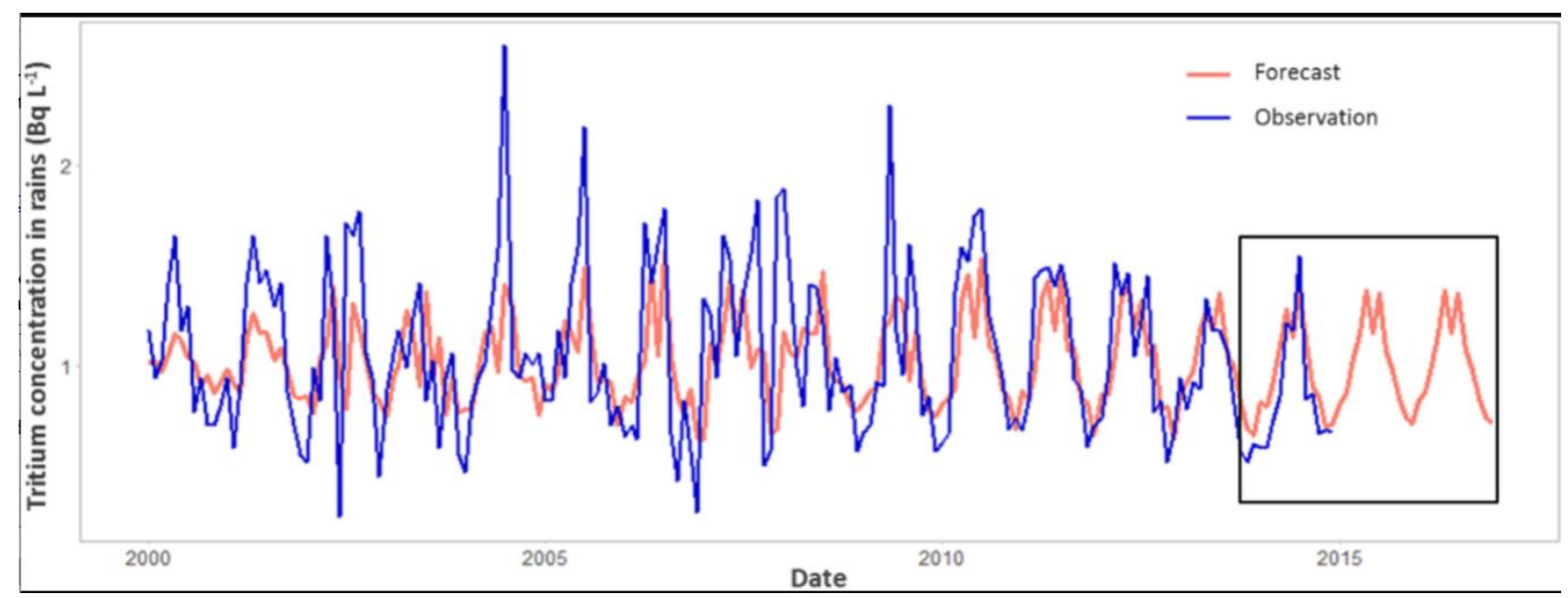

1. Download : Download high-res image (286KB)

2. Download: Download full-size image

Fig. 3. Monthly tritium concentrations in rains in Thonon-les-Bains from January 2000 to December 2016. The blue line represents tritium concentrations measured and the red line depicts tritium concentrations forecasted. The black frame represents the period in which data are used in this study. (For interpretation of the references to color in this figure legend, the reader is referred to the web version of this article.)

It clearly appears in Fig. 3 that there has been a good agreement between modelled and measured data, especially since January 2010.

In the Northern hemisphere, where tritium releases from atmospheric nuclear weapon tests were the highest, current studies show that tritium concentrations in rainfall had been decreasing since 1963 (Varlam et al., 2012) and have been stabilising for a few years. This stabilisation has been observed since 1992 in the USA by Eastoe et al. (2012) and the concentrations registered were estimated in 2013 to be representative of pre-nuclear concentrations in rains (Harms et al., 2016) in agreement with concentrations reported by Craig and Lal (1961) and Roether (1968) respectively ranged from $0.07 \mathrm{~Bq} \mathrm{~L}^{-1}$ (for Hawaiian rains) to $1.46 \mathrm{~Bq} \mathrm{~L}^{-1}$ (for Greenland snow) and $0.6 \mathrm{~Bq} \mathrm{~L}^{-1}$. The same trend is highlighted in the Southern hemisphere with a stabilisation of tritium concentration in Australia at lower concentrations i.e. around $0.3 \mathrm{~Bq} \mathrm{~L}^{-1}$ (Cartwright and Morgenstern, 2015, Tadros et al., 2014). The reason of this contrast between Australian and mid-latitude tritium concentrations is mainly due to less historical atmospheric nuclear weapon testing and could be explained by other parameters such as lower latitude or a greater oceanic influence containing less tritium for precipitations in Australia. In this way, the current concentrations in rains measured in our sampling area, are representative of natural input over the study period. 
Moreover, seasonal and natural variations due to cosmogenic production of tritium in the upper atmosphere are clearly perceptible on the measures of tritium concentration in rains in Thonon-les-Bains (Fig. 3) (Araguás-Araguás and Diaz Teijeiro, 2005, Cauquoin et al., 2015, Hayashi et al., 1999). Several mechanisms of tritium transfer from the stratosphere to the troposphere are established to understand these seasonal variations. First of all, tritium concentrations in the stratosphere are higher by several orders of magnitude than the natural tritium concentrations in precipitation (Cauquoin et al., 2015). The most important phenomenon is the "spring leak", an increase in tritium concentrations in the troposphere on the Northern hemisphere each year at that season. This mechanism is classically explained by the exchange of tropospheric and stratospheric air masses occurring predominantly during late winter and spring in the region of baroclinic zones and tropopause discontinuities located at the mid-latitudes (Jordan et al., 2003, Newell, 1963, Pedro et al., 2011, Rozanski et al., 1991). The other identified mechanisms are the eddy diffusion across the tropopause, roughly uniform over the whole Earth surface and the tritium injections by jet streams as well as the role of the Hadley cells (Ehhalt, 1971). The Hadley cell circulation would then govern tropospheric tritium concentrations in January in the Northern tropical belt, and in July in the Southern one. However, in our study, seasonal variations are characterized by highest tritium concentrations in spring (essentially from April to June), not only during summer, in accordance with tritium variations measured in Spain Araguás-Araguás and Diaz Teijeiro (2005). In addition, Radwan et al. (2001) and Cauquoin et al. (2015) showed similar seasonal variations, respectively in Warsaw in Poland (from 1994 to 1999) and in Vienne in Austria (from 2000 to 2008) with a spring-summer maximum. This peak can be explained by the importance of the spring leak which is particularly important for mid-latitudes.

\subsection{Data sets}

Tritium concentrations in rivers out of influence of nuclear releases are compiled in the Table. $\underline{1}$, with other parameters used to investigate relations such as monthly precipitations, hydrological data, watershed area, altitude and latitude.

Table 1. List of 41 water samples for the 17 rivers investigated (in the case of two sample stations on a given river, ${ }^{(a)}$ represents the upstream station and ${ }^{(b)}$ the downstream station) with environmental parameters (name of rivers, latitude, sampling date, tritium concentration in rivers, average monthly discharge, tritium concentration in rains, monthly precipitation, altitude and watershed area) for each sampling station used during the statistical analyse. * represents forecasted results for tritium concentrations in rains. Minimum, maximum, average and standard deviation are also presented.

\begin{tabular}{|c|c|c|c|c|c|c|c|c|}
\hline Rivers & $\begin{array}{l}\text { Sampli } \\
\text { ng date }\end{array}$ & $\begin{array}{c}\text { Latitu } \\
\text { de }\end{array}$ & $\begin{array}{c}\text { Watersh } \\
\text { ed area } \\
\left(\mathbf{k m}^{2}\right)\end{array}$ & $\begin{array}{l}\text { Altitu } \\
\text { de (m) }\end{array}$ & $\begin{array}{l}\text { Monthly } \\
\text { precipitati } \\
\text { on }(\mathbf{c m})\end{array}$ & $\begin{array}{c}\text { Averag } \\
\text { e } \\
\text { monthl } \\
\text { y } \\
\text { dischar } \\
\text { ge } \\
\left(\mathbf{m}^{3} \mathbf{s}^{-1}\right)\end{array}$ & $\begin{array}{l}\text { Tritium } \\
\text { concentrati } \\
\text { on in rivers } \\
\left(\mathbf{B q} \mathbf{L}^{-1}\right)\end{array}$ & $\begin{array}{c}\text { Tritium } \\
\text { concentrati } \\
\text { on in rains } \\
\left(\mathbf{B q} \mathbf{L}^{-1}\right)\end{array}$ \\
\hline Agly & Sep-16 & $\begin{array}{l}42.773 \\
6\end{array}$ & 1047.85 & 42 & 17.5 & 0.39 & $0.45 \pm 0.02$ & $0.98 *$ \\
\hline Agout $^{(a)}$ & Feb-15 & $\begin{array}{l}43.637 \\
9\end{array}$ & 849.354 & 222 & 114 & 33.9 & $0.58 \pm 0.17$ & $0.87 *$ \\
\hline
\end{tabular}


Averag

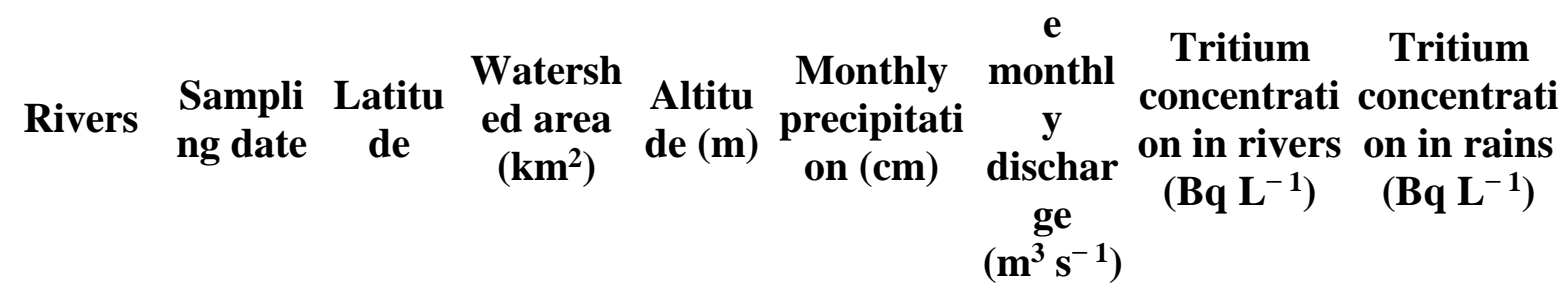

\begin{tabular}{|c|c|c|c|c|c|c|c|c|}
\hline Agout $^{(b)}$ & Feb-15 & $\begin{array}{l}43.701 \\
1\end{array}$ & 2555.6 & 131 & 69.1 & 105 & $0.40 \pm 0.16$ & $0.87^{*}$ \\
\hline $\begin{array}{l}\text { Ardèche } \\
\text { (a) }\end{array}$ & Apr-15 & $\begin{array}{l}44.644 \\
8\end{array}$ & 303.202 & 250 & 110.5 & 9.82 & $0.47 \pm 0.15$ & $1.16^{*}$ \\
\hline $\begin{array}{l}\text { Ardèche } \\
\text { (b) }\end{array}$ & Dec-15 & $\begin{array}{l}44.302 \\
5\end{array}$ & 2270.34 & 71 & 10.6 & 27.5 & $0.55 \pm 0.02$ & $0.71^{*}$ \\
\hline $\begin{array}{l}\text { Ardèche } \\
\text { (b) }\end{array}$ & Aug-16 & $\begin{array}{l}44.302 \\
5\end{array}$ & 2270.34 & 71 & 16.9 & 7.98 & $0.76 \pm 0.08$ & $1.08 *$ \\
\hline $\begin{array}{l}\text { Ardèche } \\
\text { (b) }\end{array}$ & Mar-14 & $\begin{array}{l}44.302 \\
5\end{array}$ & 2270.34 & 71 & 32.4 & 63.2 & $0.86 \pm 0.15$ & 0.73 \\
\hline Argens & Jul-16 & $\begin{array}{l}43.423 \\
5\end{array}$ & 2697.95 & 7 & 4 & 3.32 & $0.44 \pm 0.06$ & $1.37 *$ \\
\hline Argens & May-14 & $\begin{array}{l}43.423 \\
5\end{array}$ & 2697.95 & 7 & 28.3 & 14.2 & $0.12 \pm 0.11$ & 1.22 \\
\hline Argens & May-14 & $\begin{array}{l}43.423 \\
5\end{array}$ & 2697.95 & 7 & 28.3 & 14.2 & $0.12 \pm 0.11$ & 1.22 \\
\hline Aude & Dec-15 & $\begin{array}{l}43.235 \\
5\end{array}$ & 5138.73 & 19 & 7.7 & 10.3 & $0.41 \pm 0.01$ & $0.71 *$ \\
\hline Aude & Dec-15 & $\begin{array}{l}43.235 \\
5\end{array}$ & 5138.73 & 19 & 7.7 & 10.3 & $0.41 \pm 0.01$ & $0.71 *$ \\
\hline Aude & Jun-16 & $\begin{array}{l}43.235 \\
5\end{array}$ & 5138.73 & 19 & 9.4 & 18.6 & $0.20 \pm 0.15$ & $1.16^{*}$ \\
\hline Aude & Apr-15 & $\begin{array}{l}43.235 \\
5\end{array}$ & 5138.73 & 19 & 43.7 & 61 & $0.29 \pm 0.15$ & $1.16^{*}$ \\
\hline Aude & Jun-16 & $\begin{array}{l}43.235 \\
5\end{array}$ & 5138.73 & 19 & 9.4 & 18.6 & $0.47 \pm 0.05$ & $1.16^{*}$ \\
\hline Cèze $^{(\mathbf{a})}$ & Apr-15 & $\begin{array}{l}44.319 \\
3\end{array}$ & 113.765 & 291 & 129.5 & 6.31 & $0.25 \pm 0.16$ & $1.16^{*}$ \\
\hline Cèze $^{(\mathbf{b})}$ & Jun-16 & $\begin{array}{l}44.205 \\
1\end{array}$ & 1020.48 & 120 & 43.8 & 4.77 & $0.65 \pm 0.05$ & $1.16^{*}$ \\
\hline Cèze $^{(\mathbf{b})}$ & May-16 & $\begin{array}{l}44.205 \\
1\end{array}$ & 1020.48 & 120 & 79.2 & 11.4 & $0.51 \pm 0.06$ & $1.38^{*}$ \\
\hline Cèze $^{(\mathbf{b})}$ & Aug-16 & $\begin{array}{l}44.205 \\
1\end{array}$ & 1020.48 & 120 & 14.5 & 1.87 & $0.63 \pm 0.07$ & $1.08 *$ \\
\hline Cèze $^{(\mathbf{b})}$ & Mar-14 & $\begin{array}{l}44.205 \\
1\end{array}$ & 1020.48 & 120 & 31.1 & 13.4 & $0.56 \pm 0.13$ & 0.73 \\
\hline $\begin{array}{c}\text { Clamou } \\
\mathbf{x}\end{array}$ & Apr-15 & $\begin{array}{l}43.302 \\
9\end{array}$ & 48.5193 & 371 & 68.7 & 2.83 & $0.22 \pm 0.15$ & $1.16^{*}$ \\
\hline
\end{tabular}


Averag

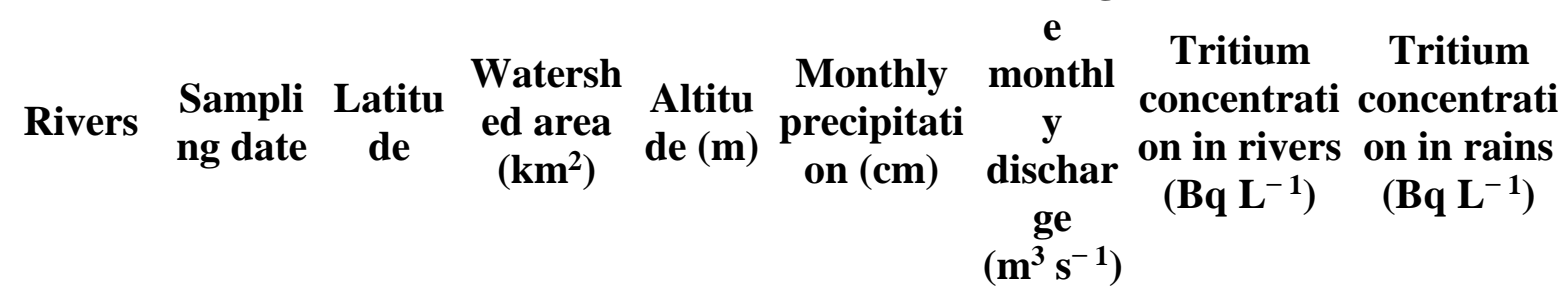

\begin{tabular}{|c|c|c|c|c|c|c|c|c|}
\hline Gapeau & Jul-16 & $\begin{array}{l}43.131 \\
1\end{array}$ & 544.85 & 2 & 2.8 & 0.23 & $0.38 \pm 0.04$ & $1.37 *$ \\
\hline Gapeau & May-14 & $\begin{array}{l}43.131 \\
1\end{array}$ & 544.85 & 2 & 32.1 & 1.98 & $0.14 \pm 0.11$ & 1.22 \\
\hline Gapeau & May-14 & $\begin{array}{l}43.131 \\
1\end{array}$ & 544.85 & 2 & 32.1 & 1.98 & $0.15 \pm 0.11$ & 1.22 \\
\hline Gardon & Sep-15 & $\begin{array}{l}43.936 \\
1\end{array}$ & 1882.44 & 22 & 31.5 & 28.7 & $0.44 \pm 0.01$ & $0.98 *$ \\
\hline Gardon & Aug-16 & $\begin{array}{l}43.936 \\
1\end{array}$ & 1882.44 & 22 & 6.5 & 3.52 & $0.47 \pm 0.04$ & $1.08^{*}$ \\
\hline $\begin{array}{c}\text { Garonn } \\
\text { e }\end{array}$ & Feb-15 & $\begin{array}{l}44.029 \\
0\end{array}$ & $15,044.5$ & 72 & 60 & 441 & $0.39 \pm 0.16$ & $0.87 *$ \\
\hline$\underset{\text { a) }}{\text { Hérault }}$ & Feb-15 & $\begin{array}{l}43.663 \\
0\end{array}$ & 1346.29 & 86 & 20.9 & 12.3 & $0.28 \pm 0.16$ & $0.87 *$ \\
\hline
\end{tabular}

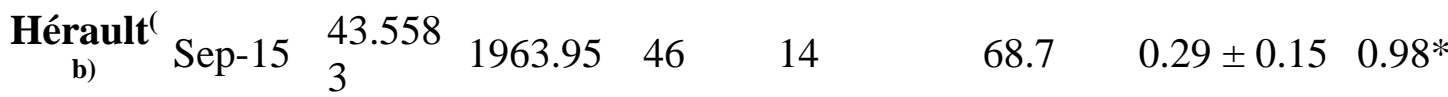

$\begin{array}{lllllllll}\text { Orb }^{(\mathbf{a})} & \text { Feb-15 } & \begin{array}{l}43.546 \\ 7\end{array} & 911.003 & 191 & 22.5 & 18.4 & 0.28 \pm 0.16 & 0.87^{*}\end{array}$

$\begin{array}{lllllllll}\text { Orb }^{(\mathbf{b})} & \text { Dec-15 } & \begin{array}{l}43.372 \\ 8\end{array} & 1336.64 & 39 & 15.4 & 8.43 & 0.34 \pm 0.01 & 0.71^{*}\end{array}$

$\begin{array}{lllllllll}\text { Orb }^{(\mathbf{b})} & \text { Jun-16 } & \begin{array}{l}43.372 \\ 8\end{array} & 1336.64 & 39 & 17.4 & 14.5 & 0.17 \pm 0.15 & 1.16^{*}\end{array}$

$\begin{array}{lllllllll}\text { Orb }^{(\mathbf{b})} & \text { Jun-16 } & \begin{array}{l}43.372 \\ 8\end{array} & 1336.64 & 39 & 17.4 & 14.5 & 0.39 \pm 0.03 & 1.16^{*}\end{array}$

$\begin{array}{llllllll}\text { Ouvèze Sep-15 } & \begin{array}{l}44.042 \\ 1\end{array} & 1905.15 & 23 & 110.1 & 8.58 & 0.52 \pm 0.02 & 0.98^{*}\end{array}$

$\begin{array}{llllllll}\text { Ouvèze Aug-16 } \begin{array}{llll}44.042 \\ 1\end{array} & 1905.15 & 23 & 9.6 & 6.11 & 0.53 \pm 0.04 & 1.08^{*}\end{array}$

$\begin{array}{lllllllll}\text { Tarn } & \text { Feb-15 } & \begin{array}{l}43.863 \\ 6\end{array} & 9141.47 & 115 & 81.5 & 215 & 0.38 \pm 0.15 & 0.87^{*}\end{array}$

$\begin{array}{lllllllll}\text { Tech } & \text { Sep-16 } & \begin{array}{l}42.523 \\ 1\end{array} & 611.204 & 88 & 40.7 & 3.7 & 0.61 \pm 0.05 & 0.98^{*}\end{array}$

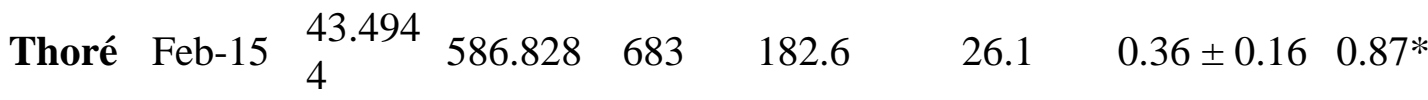

$\begin{array}{llllllll}\text { Var Jul-16 } & \begin{array}{l}43.682 \\ 6\end{array} & 2818.15 & 333 & 1.2 & 28.4 & 0.60 \pm 0.04 & 1.37^{*}\end{array}$

$\begin{array}{llllllll}\text { Var } & \text { May-14 } \begin{array}{lllll}43.682 \\ 6\end{array} & 2818.15 & 333 & 19.2 & 87.9 & 0.22 \pm 0.15 & 1.22\end{array}$ 


\begin{tabular}{|c|c|c|c|c|c|c|c|c|}
\hline Rivers & $\begin{array}{l}\text { Sampli } \\
\text { ng date }\end{array}$ & $\begin{array}{c}\text { Latitu } \\
\text { de }\end{array}$ & $\begin{array}{c}\text { Watersh } \\
\text { ed area } \\
\left(\mathbf{k m}^{2}\right)\end{array}$ & $\begin{array}{l}\text { Altitu } \\
\text { de (m) }\end{array}$ & $\begin{array}{l}\text { Monthly } \\
\text { precipitati } \\
\text { on }(\mathbf{c m})\end{array}$ & $\begin{array}{c}\text { Averag } \\
\text { e } \\
\text { monthl } \\
\text { y } \\
\text { dischar } \\
\text { ge } \\
\left(\mathbf{m}^{3} \mathbf{s}^{-1}\right)\end{array}$ & $\begin{array}{l}\text { Tritium } \\
\text { concentrati } \\
\text { on in rivers } \\
\left(\mathbf{B q} \mathbf{L}^{-1}\right)\end{array}$ & $\begin{array}{c}\text { Tritium } \\
\text { concentrati } \\
\text { on in rains } \\
\left(\mathbf{B q} \mathbf{L}^{-1}\right)\end{array}$ \\
\hline Var & May-14 & $\begin{array}{l}43.682 \\
6\end{array}$ & 2818.15 & 333 & 19.2 & 87.9 & $0.42 \pm 0.32$ & 1.22 \\
\hline $\begin{array}{l}\text { Min } \\
\text { value }\end{array}$ & Mar-14 & 42.52 & 48.52 & 2 & 1.2 & 0.23 & 0.12 & 0.71 \\
\hline $\begin{array}{c}\text { Max } \\
\text { value }\end{array}$ & Sep-16 & 44.64 & $\begin{array}{l}15,044.5 \\
0\end{array}$ & 683 & 182.6 & 441.0 & 0.86 & 1.38 \\
\hline $\begin{array}{c}\text { Average } \\
(\mu)\end{array}$ & Jan-16 & 43.65 & 2460.44 & 112 & 39.3 & 37.0 & 0.41 & 1.05 \\
\hline $\begin{array}{c}\text { Standar } \\
\text { d } \\
\text { deviatio } \\
\text { n }(\sigma)\end{array}$ & & 0.47 & 2717.05 & 140 & 40.7 & 76.0 & 0.17 & 0.20 \\
\hline
\end{tabular}

Based on 41 water samples collected between March 2014 and September 2016, the environmental background for tritium concentrations (HTO) ranged from $0.12 \pm 0.11 \mathrm{~Bq} \mathrm{~L}^{-1}$ for the Argens River to $0.86 \pm 0.15 \mathrm{~Bq} \mathrm{~L}^{-1}$ for the Ardèche River (Fig. 1). In this study, HTO concentrations are close to those measured by Harms et al. (2016) in US surface water ranging from around $0.2 \mathrm{~Bq} \mathrm{~L}^{-1}$ to $0.4 \mathrm{~Bq} \mathrm{~L}^{-1}$ from 2013 to 2014 . Measured or estimated HTO concentrations in rains in Thonon-les-Bains over the same period were almost always significantly higher and ranged from 0.71 to $1.38 \mathrm{~Bq} \mathrm{~L}^{-1}$. On these 41 analysed samples, the average HTO concentration in rivers $\left(\mu=0.41 \mathrm{~Bq} \mathrm{~L}^{-1} \sigma=0.17 \mathrm{~Bq} \mathrm{~L}^{-1}\right)$ was more than twice lower than in rains $\left(\mu=1.05 \mathrm{~Bq} \mathrm{~L}^{-1} \sigma=0.20 \mathrm{~Bq} \mathrm{~L}^{-1}\right)$. The lowest value for tritium concentrations in precipitations was observed in December 2015 while the highest referred to May 2016. The data sets showed that generally HTO concentrations in rains display a seasonal trend characterized with lower concentrations in winter than at the late spring and summer as discussed earlier.

In order to visualise the density distribution for each parameter, data are represented under the form of violin plots (Fig. 4). This kind of graph is interesting to view the homogeneity or heterogeneity of results. 


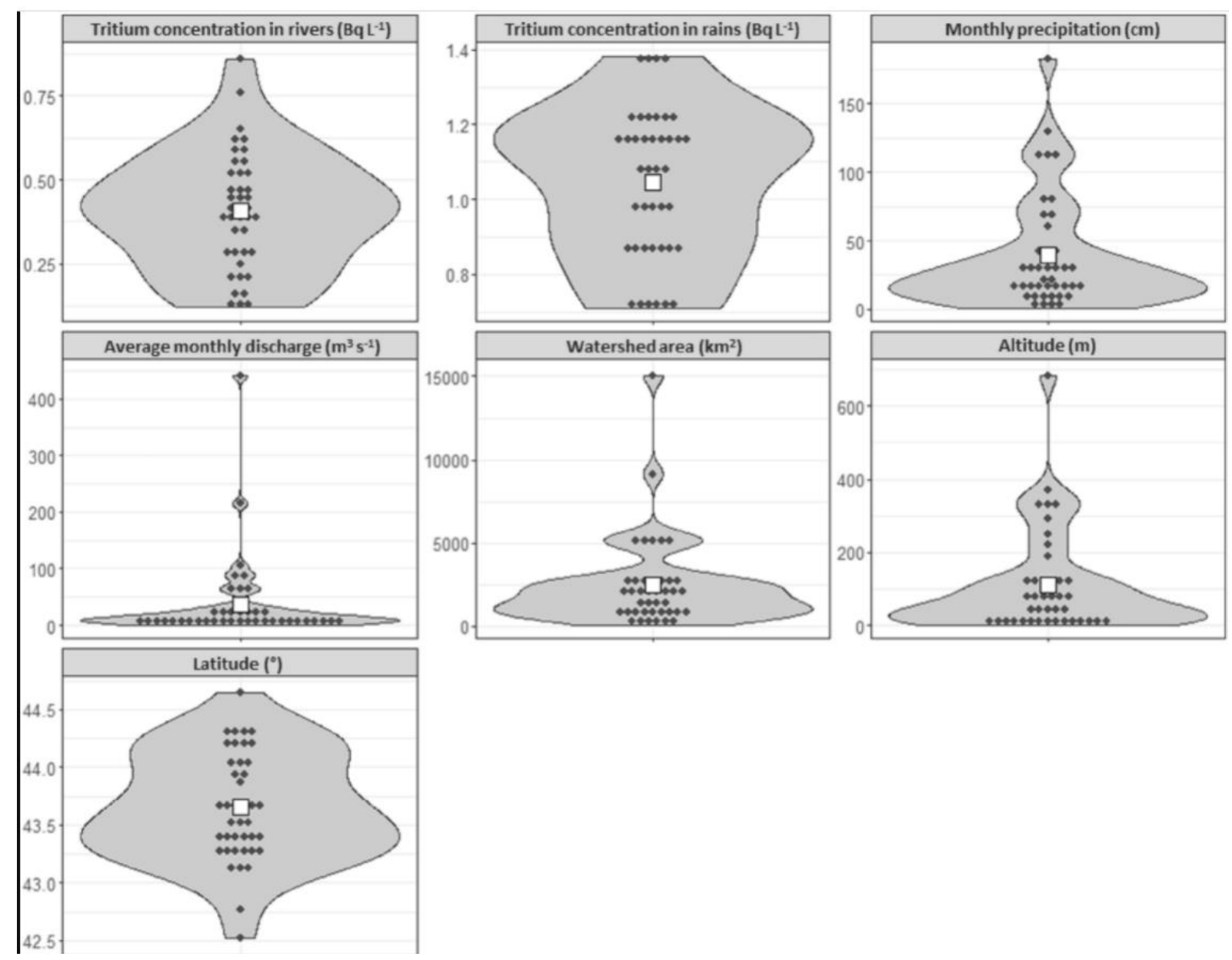

1. Download : Download high-res image (543KB)

2. Download : Download full-size image

Fig. 4. These violin plots represent the density distribution. Points represent the results for each variable and grey surfaces the distribution density by value. The white square represents the average for each parameter.

The surface of the studied watersheds and the mean monthly water discharges varied over a large range of values, i.e., from 48.52 to $15,044.50 \mathrm{~km}^{2}\left(\sigma=1684.75 \mathrm{~km}^{2}\right)$ and from 0.23 to $441 \mathrm{~m}^{3} \mathrm{~s}^{-1}\left(\sigma=75.95 \mathrm{~m}^{3} \mathrm{~s}^{-1}\right)$ respectively. Monthly precipitation, ranged from 1.20 to $182.60 \mathrm{~cm}(\mu=39.34 \mathrm{~cm}$ and $\sigma=30.34 \mathrm{~cm})$ and altitude ranged from 2 to $683 \mathrm{~m}$ $(\mu=112.41 \mathrm{~m}$ and $\sigma=99.84)$ also rather heterogeneous even though most samples $(88 \%)$ were collected at an altitude below $300 \mathrm{~m}$. On the contrary, the latitude values are relatively homogenous (ranged from 42.5231 to 44.6448 ) since the location of the study area is limited to the south of France. Furthermore, these values are close to the latitude in Thonon-les-Bains (46.3708).

The difference between HTO concentrations in rains and rivers reflects both the residence time of water masses at the scale of the watershed and the mixing of river waters with groundwater most generally depleted in tritium when compared to superficial waters (Gusyev et al., 2013). Within the study area, groundwater is often the predominant water component in rivers, especially during base flow conditions (Solder et al., 2016, Uhlenbrook et al., 2002, Ward and Robinson, 1967). 


\subsection{Potential relationship between tritium concentrations in rains and rivers}

In order to study the relationship between tritium concentrations in rains and rivers, observed concentrations in all the rivers for a given month were averaged to obtain the same time step as the rain series. The result is presented in Fig. 5.

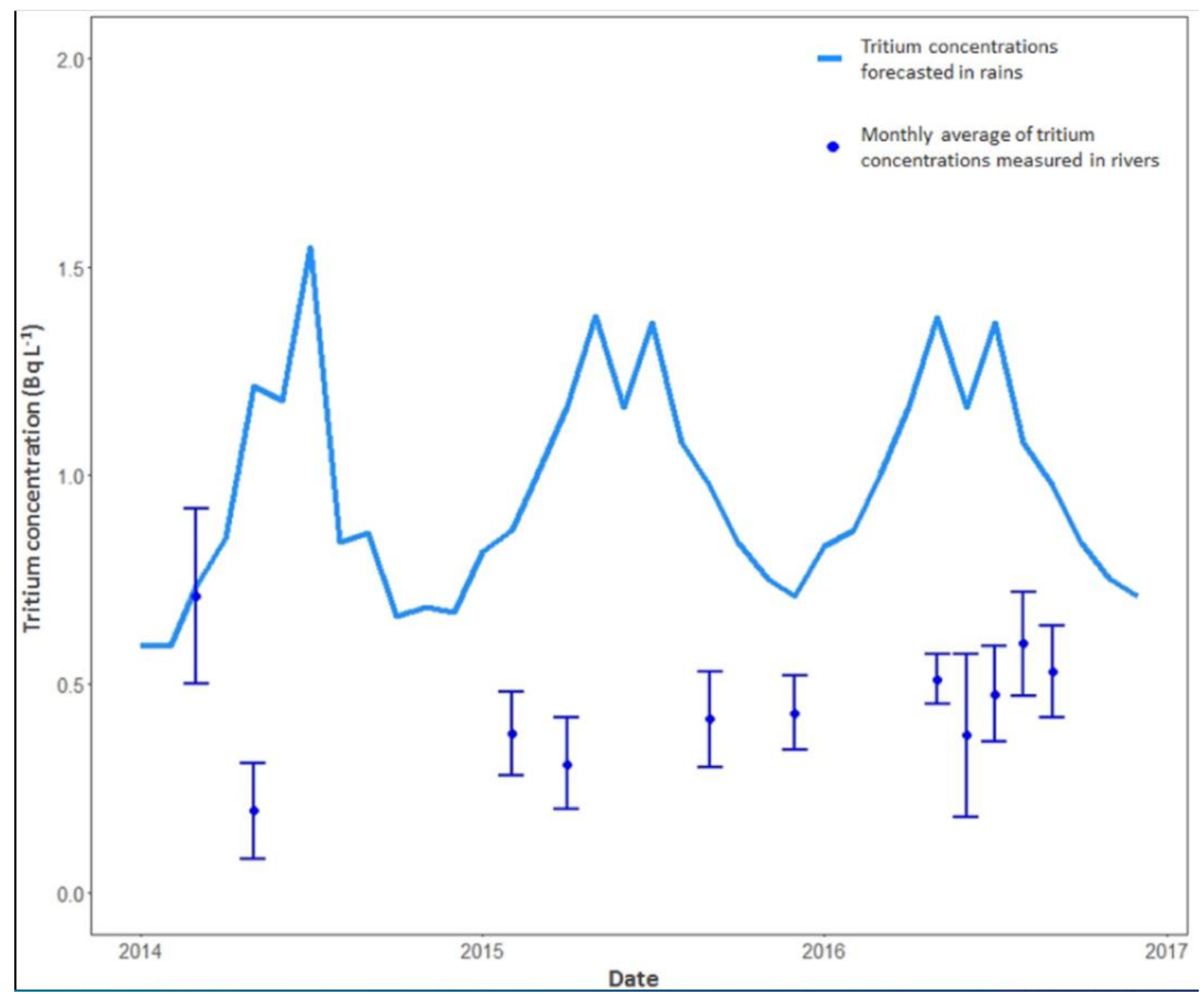

1. Download : Download high-res image (232KB)

2. Download : Download full-size image

Fig. 5. Comparison between monthly tritium concentrations forecasted in rains in Thonon-lesBains (blue line) and monthly average of tritium concentrations measured in all the rivers investigated (blue points) (blue error bars represent standard deviation). (For interpretation of the references to color in this figure legend, the reader is referred to the web version of this article.)

In Fig. 5, tritium concentrations are clearly higher in rains compared to rivers investigated. The strong seasonality observed in rains is not reflected in the river series contrary to several studies (Hadžišehović et al., 1978, Michel et al., 2013). Different processes lead to smooth the amplitude of the seasonality in rivers such as mixing and storage processes such as those that occur in lakes, reservoirs, and groundwater (Halder et al., 2015). The influx of younger water or recent rains poor in tritium combined to base flow for most Northern Hemisphere rivers also conduced to decrease the seasonality (Michel et al., 2013, Rank et al., 1998) (young 
groundwater is younger than 100 years old, while groundwater recharged past 50 years, since the nuclear weapon tests, is considered modern (Bethke and Johnson, 2008, Gleeson et al., 2016, Kazemi et al., 2006)). Furthermore, Harms et al. (2016) have not found a clear relation between seasonal variation of tritium in rainfall and tritium concentrations in river water. In our study, the lack of seasonality could be explained by the Mediterranean climatic context which is characterized by mild wet winters and warm and dry summers and more particularly by very uneven distribution of precipitation throughout the year (Lionello et al., 2006). The impact of atmospheric moisture on tritium concentrations in rivers (or rains) is particularly important for coastal systems because the marine compartment is least concentrated in tritium (tritium concentrations are most of the time lower than $0.12 \mathrm{~Bq} \mathrm{~L}^{-1}$ ) (Povinec et al., 2017). Indeed, rain dilution by marine moisture characterized by low tritium concentrations has been observed in several places around the world such as islands (e.g., Japan, Ireland) (Okai et al., 1999, Radwan et al., 2001, Weiss et al., 1979), places under monsoon phenomenon (Bhattacharya et al., 2003) or seashore region (Bhattacharya et al., 2003, Radwan et al., 2001).

The hydrogeological context is an important factor due to its complexity with a high heterogeneity (different kinds of lithology) sometimes within a same watershed generating very different groundwater residence times.

Tritium concentrations in rains and rivers were standardized for each watershed in order to provide a monthly activity of tritium for each sampling station with the aim of establishing potential relationships between tritium concentration in rivers and environmental parameters identified i.e. tritium concentrations in rains, watershed area, altitude, latitude and monthly precipitation.

For tritium concentrations in rains, a monthly tritium activity deposited by rains was estimated and defined as an "Input" (Eq. (1)).

$$
\text { Input }=\left[{ }^{3} H\right]_{\text {rains }} \times M P \times W A
$$

with $\left[{ }^{3} \mathrm{H}\right]_{\text {rains }}$ is the monthly tritium concentration in rains $\left(\mathrm{Bq} \mathrm{m}^{-3}\right), M P$ is the monthly precipitation $(\mathrm{m}), W A$ is the Watershed area $\left(\mathrm{m}^{2}\right)$. Input is expressed in Bq.

For tritium concentrations in river water, a monthly tritium activity exported by rivers was estimated and defined as an "Output" (Eq. (2)).

$$
\begin{aligned}
& \text { Output }=\left[{ }^{3} H\right]_{\text {rivers }} \\
& \times\left(Q_{\text {Monthly }} \times 1000 \times(3600 \times 24 \times 30)\right)
\end{aligned}
$$

with $\left[{ }^{3} H\right]_{\text {rivers }}$ is the monthly tritium concentration in rivers $\left(\mathrm{Bq} \mathrm{L}^{-1}\right), Q_{M o n t h l y}$ is the average monthly discharge $\left(\mathrm{m}^{3} \mathrm{~s}^{-1}\right)$. Output is expressed in Bq. 
In this way, the tritium activity Input within the watershed by rainfalls and Output by the river can be compared (Fig. 6).

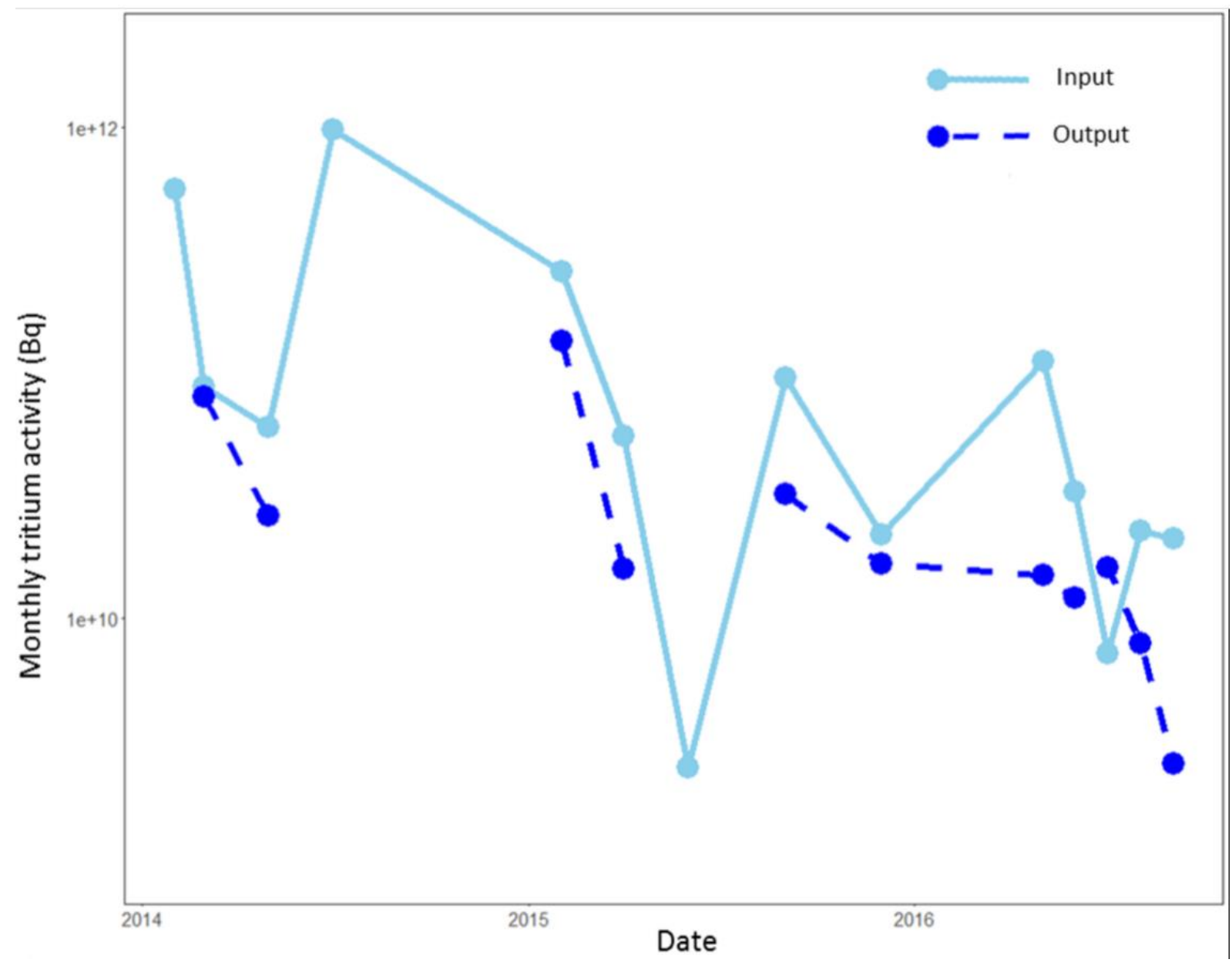

1. Download : Download high-res image (167KB)

2. Download : Download full-size image

Fig. 6. Comparison between the monthly tritium activity deposited by rains (Input) depicted by the light blue curve line and the monthly tritium activity exported by all rivers (Output) represented by the dark blue dotted line. (For interpretation of the references to color in this figure legend, the reader is referred to the web version of this article.)

The calculation of Input and Output allows the use of multiple linear regression without having to worry about spatialisation of rains and climate properties own to Mediterranean context. This approach of monthly activity enables the calculation of tritiated water balance between Input and Output.

Starting from this part, tritium concentrations in rains and rivers are expressed as Input and Output respectively.

\subsection{Impact assessment of multiple variables on monthly tritium activity in rivers}


The results of the multiple linear regression led to identify the main parameters which are correlated with $\log _{10}$ (Output) are presented in Table. 2. The right hand column represents the results of the multiple linear regression after adjustment of the p-value to maintain an overall alpha risk of 5\%. The relation is linear and significant if the p-value is fall short of 0.05 .

Table 2. Results of the multiple linear regression between $\log _{10}$ of Output and other environmental parameters: $\log _{10}$ of Input, $\log _{10}$ of Watershed area, Altitude, Latitude and Monthly precipitations. Results of the river random effect are presented at the top of the table. Adjusted p-value are displayed in bold. Concerning fixed effects, "**” highlights a significant, positive and linear relationship between output and explanatory variable, whereas "*” shows a positive linear relationship approaching the significance. "Intercept" represents the expected mean value of Output ( $\log _{10}$ transformed) when all explanatory variables are equal to zero.

\section{Random effects}

Groups Variance Std. dev.

$\begin{array}{crr}\text { River } & 0.1185 & 0.3443 \\ \text { Residual } 1.0401 & 1.0199\end{array}$

Fixed effects

\begin{tabular}{|c|c|c|c|c|}
\hline & Estimate & $\begin{array}{l}\text { Degree of } \\
\text { freedom }\end{array}$ & t value & $\begin{array}{l}\text { Adjusted p- } \\
\text { value }\end{array}$ \\
\hline Intercept & $-2.310 \mathrm{e}+01$ & $1.154 \mathrm{e}+011.252 \mathrm{e}+01$ & -2.002 & 0.1751 \\
\hline $\log _{10}($ Inputs $)$ & $5.963 e-01$ & $1.996 \mathrm{e}-012.678 \mathrm{e}+01$ & 2.988 & $0.0124 * *$ \\
\hline $\begin{array}{c}\log _{10} \text { (Watershed } \\
\text { area) }\end{array}$ & $6.486 \mathrm{e}-01$ & $2.790 \mathrm{e}-013.307 \mathrm{e}+01$ & 2.325 & $0.0834 *$ \\
\hline Altitude & $2.309 e-03$ & $8.105 \mathrm{e}-042.465 \mathrm{e}+01$ & 2.849 & $0.0191 * *$ \\
\hline Latitude & $3.929 \mathrm{e}-06$ & $1.855 \mathrm{e}-061.242 \mathrm{e}+01$ & 2.118 & 0.1363 \\
\hline $\begin{array}{c}\text { Monthly } \\
\text { precipitation }\end{array}$ & $-3.173 e-03$ & $3.104 \mathrm{e}-033.028 \mathrm{e}+01$ & -1.022 & 0.7608 \\
\hline
\end{tabular}

These statistical analyses highlight that two parameters ( $\log _{10}$ (Input) and Altitude) have been clearly identified to be positively and significantly correlated with monthly tritium activity exported by rivers (Output). In addition, a positive linear relationship approaching the significance has been found between $\log _{10}$ (Watershed area) and Output. Concerning random effect, intra-class correlation coefficient (i.e., correlation between measurements of the same river) is weak, about $0.1(0.1185 /(0.1185+1.0401))$ (Table. 2$)$.

Among the results of the statistical analysis, the linear positive relationship between $\log _{10}$ (Output) and $\log _{10}$ (Input) is the most significant (with a p-value equal to 0.0124). The study of Danube Tisa and Sava Rivers (Europe) led by Hadžišehović et al. (1978) and Hadžišehović et al. (1982) showed concomitant variations of tritium concentration in river and precipitations even though less pronounced amplitude for river water. Variations of tritium concentrations in river waters were most likely rather due to impact of tritium concentrations in groundwater than snowmelt according to climatic conditions in these areas.

The altitudes of sampling stations ranged from $2 \mathrm{~m}$ to $683 \mathrm{~m}$. Most of the sampling stations were near sea level, however a significant, positive and linear relationship appeared between 
Output and altitude (with a p-value equal to 0.0191). No studies have been led to investigate clearly the influence of altitude on tritium concentrations in rivers. Nonetheless, Harms et al. (2016) highlighted the expected increasing trend of tritium concentrations on the one hand with inland distance due to the decreasing of moisture coming from ocean and on the other hand with altitude due to lower mixing between water surface and groundwater in higher elevation. Jouzel et al. (1977) have observed an altitude effect in the distribution of deuterium and tritium in the precipitation in the Mont Blanc area (culminating at $4809 \mathrm{~m}$ ) with tritium concentrations in the Mont Blanc snow 2.2 times higher than in Thonon-les-Bains precipitation (altitude of $385 \mathrm{~m}$ ) for the period extending from winter 1971 to June 1973. These observations were explained on the one hand by the clouds penetration at the higher altitudes throughout the higher layers of the troposphere and the incorporation of enriched tritium moisture and on the other hand, by the isotopic exchanges between liquid water and atmospheric moisture depleted in tritium in the low tropospheric layers (Jouzel et al., 1977).

In addition, a positive linear relationship approaching the significance appeared between $\log _{10}$ (Outputs) and $\log _{10}$ (Watershed area) with an adjusted p-value $<0.1$. In contrast with Cartwright and Morgenstern (2015) who not observed any positive correlation between an Australian catchment area and tritium concentrations (but a correlation with the runoff coefficient), a positive relationship was mentioned by Radwan et al. (2001) showing lower annual average tritium concentrations in rivers characterized by smaller drainage areas (around 10\% of other watershed investigated). For Momoshima et al. (1991), the larger area of islands studied would cause longer residence time of groundwater due to larger size of the reservoir and could explain, with the hydrogeological background, the differences observed in tritium concentrations in various rivers of different islands. Indeed, the base flow of a river is generally composed of water that was retained in the basin at timescales in the order of a decade, labelled by global fallout and reflect the higher tritium concentrations found during the earlier part of the tritium transient (Michel et al., 2013).

In this work, no significant relationship appeared between $\log _{10}($ Output) and monthly precipitation in agreement with the observations of Radwan et al. (2001), Tadros et al. (2014) and Hadžišehović et al. (1978). Besides, Tonosaki et al. (2000) noticed that tritium concentrations in water of a Japanese lagoon (Obuchinuma Lake) were not significantly influenced by precipitation but depend generally on other parameters such as the ratio of seawater and river influx.

Similarly, no significant relationship appeared between $\log _{10}($ Output $)$ and Latitude. The lack of correlation was expected is our case because all sampling stations were closed in terms of latitude, i.e. located in the southern part of France with values ranging ranged from 42.5231 to 44.6448. However, this is a key parameter and lots of studies have demonstrated the relationship between tritium concentrations in rains and latitude. Indeed, Stewart and Farnsworth (1968), Momoshima et al. (1991) and Rozanski et al. (1991) showed increasing tritium concentration in precipitations at an exponential rate from the equator to the pole, which double about every $13^{\circ}$ of latitude. The same phenomenon, linked to the origin and dynamic of air masses, has been highlighted by Tadros et al. (2014) in precipitation across Australia and by Hadžišehović et al. (1982) when the air masses from higher latitudes penetrate in Europe often by western and north-western air streams.

\subsection{Estimation of tritium fluxes exported by French coastal rivers to the Mediterranean Sea}


A rough estimate of tritium fluxes exported by major French coastal rivers to the

Mediterranean Sea were performed in order to compare them with those delivered by the Rhône River which is the main River in this area. Mean annual flow values for the coastal rivers located to the west of the Rhône river were extracted from (Bourrin et al., 2006, Marion, 2010) and for the Rhône River, flow rates were measured in Arles (IRSN-SORA monitoring station). Flow rates in Argens, Var and Gapeau Rivers were extracted from Banque HYDRO - MEEDDAT/DGPR/SRNH.

Annual fluxes were calculated by the following equation (Eq. (3))

$$
F_{\text {tritium }}=\left[{ }^{3} H\right] \times 1000 \times Q_{\text {annually }}
$$

where $\left[{ }^{3} H\right]$ is the tritium concentration in rivers $\left(\mathrm{Bq} \mathrm{L}^{-1}\right)$ and $Q_{\text {annually }}$ is the mean annual flowrate $\left(\mathrm{m}^{3}\right.$ year $\left.{ }^{-1}\right) . F_{\text {tritium }}$, the annual flux of tritium is expressed in $\mathrm{Bq}_{\text {year }}{ }^{-1}$.

In order to present a range of tritium fluxes exported only by coastal rivers, minimum and maximum concentrations measured during the sampling period were used (respectively equal to 0.12 and $0.61 \mathrm{~Bq} \mathrm{~L}^{-1}$ ) and are presented in the Table. 3 .

Table 3. List of coastal rivers used to estimate fluxes of tritium delivered to the Mediterranean Sea. Mean annual flowrate used for each river and minimum and maximum fluxes of tritium associated.

\begin{tabular}{|c|c|c|c|}
\hline Rivers & $\begin{array}{l}\text { Mean annual flowrate } \\
\left(10^{6} \mathrm{~m}^{3} \text { year }^{-1}\right)\end{array}$ & $\begin{array}{l}\text { Minimum tritium flux } \\
\text { exported by rivers } \\
\left(\text { Bq year }{ }^{-1}\right)\end{array}$ & $\begin{array}{l}\text { Maximum tritium flux } \\
\text { exported by rivers } \\
\left(\text { Bq year }{ }^{-1}\right)\end{array}$ \\
\hline Tech & 301.5 & $3.62 \mathrm{e}+10$ & $1.84 \mathrm{e}+11$ \\
\hline Têt & 341.5 & $4.10 \mathrm{e}+10$ & $2.08 \mathrm{e}+11$ \\
\hline Agly & 193.4 & $2.32 \mathrm{e}+10$ & $1.18 \mathrm{e}+11$ \\
\hline Aude & 1197.6 & $1.44 \mathrm{e}+11$ & $7.31 \mathrm{e}+11$ \\
\hline Orb & 841.6 & $1.01 \mathrm{e}+11$ & $5.13 e+11$ \\
\hline Hérault & 1281.6 & $1.54 \mathrm{e}+11$ & $7.82 \mathrm{e}+11$ \\
\hline Lez & 68.7 & $8.24 \mathrm{e}+09$ & $4.19 e+10$ \\
\hline Vidourle & 215.4 & $2.59 e+10$ & $1.31 \mathrm{e}+11$ \\
\hline Argens & 781.0 & $9.37 \mathrm{e}+10$ & $4.76 e+11$ \\
\hline Var & 1698.7 & $2.04 \mathrm{e}+11$ & $1.04 \mathrm{e}+12$ \\
\hline Gapeau & 199.0 & $2.39 e+10$ & $1.21 \mathrm{e}+11$ \\
\hline Total & 7120.14 & $8.54 \mathrm{e}+11$ & $4.34 \mathrm{e}+12$ \\
\hline
\end{tabular}

Liquid fluxes delivered by the main French coastal rivers to the Mediterranean Sea represent $11.3 \%$ of total fluxes against $88.7 \%$ delivered by the Rhône River (liquid discharges around $55.8 \times 10^{9} \mathrm{~m}^{3}$ year $\left.^{-1}\right)$. However, tritium fluxes exported by all the small coastal rivers ranged from $0.85 \mathrm{TBq}(0.29 \%$ of total fluxes) to $4.34 \mathrm{TBq}$ (around $1.5 \%$ of total fluxes). Those delivered by the Rhône River are largely prevailing and represent around $293 \mathrm{TBq}$ per year (between 98.5 and $99.7 \%$ of total fluxes of liquid tritium mainly from anthropogenic sources). 
The proportions of naturally occurring tritium in this latter river is estimated at $<5 \%$, with the remaining amount arising from nuclear facilities (Eyrolle-Boyer et al., 2015).

These global estimations highlight the importance of the amount of tritiated water delivered by the Rhône River towards the Mediterranean Sea, due to large amount of tritium controlled discharges, in comparison to other French coastal rivers. It seems interesting to estimate fluxes for other forms of tritium (Organically Bound Tritium, tritiated luminous compound and other tritiated molecules) in order to compare them with fluxes of tritiated water.

\section{Conclusion}

Throughout the sampling period from March 2014 to September 2016, tritiated water concentrations were measured in 17 rivers located in the Southern part of France that were not directly influenced by the releases from nuclear facilities. Tritium concentrations in river waters ranged from $0.12 \pm 0.11 \mathrm{~Bq} \mathrm{~L}^{-1}$ for the Argens River to $0.86 \pm 0.15 \mathrm{~Bq} \mathrm{~L}^{-1}$ for the Ardèche River. A significant variability of tritium concentrations in river waters studied was highlighted. Those concentrations were more than twice lower than forecasted values in rain waters which ranged from 0.73 to $1.22 \mathrm{~Bq} \mathrm{~L}^{-1}$ in Thonon-les-Bains during the same period. These differences are closely linked to both the residence time of groundwater bodies at the scale of the watershed and their mixing with river waters. Tritium concentrations in rivers do not demonstrate any seasonality contrary to tritium in rain in Thonon-les-Bains. However, a relationship between tritium activity Input (monthly tritium activity deposited by rains) and Output (monthly tritium activity exported by rivers) was obtained. Additionally, in order to explain both temporal and spatial variability of tritium concentrations in river waters, a multiple linear regression approach was used and highlighted a significant, positive and linear relationship between the $\log _{10}$ of Output and two environmental parameters: the $\log _{10}$ of Input and altitude, but also a positive linear relationship approaching the significance between Outputs and the $\log _{10}$ of the catchment area. Furthermore, this statistical analysis showed a lack of relationship between $\log _{10}$ Output and both latitude and monthly precipitation. The characterization of those parameters will allow predicting tritium concentrations in other river waters provided all affecting parameters including groundwater are known gaining access to improve radiological impact studies anywhere at the global scale.

Finally, tritium fluxes exported towards the Mediterranean Sea by the main French non nuclearized coastal rivers, ranged from 0.85 to $4.34 \mathrm{TBq}$ per year which represent only 0.29 to $1.5 \%$ of total tritium fluxes delivered in this area though these rivers contribute to $>10 \%$ of the liquid fluxes. Indeed, the Rhône River exports up to $293 \mathrm{TBq}$ per year (i.e., 98.5 to 99.7\%) mainly due to the releases from nuclear facilities which confirm that the Rhône River is the main tritium land-based source for the Northwestern Mediterranean Sea.

\section{Acknowledgements}

This work was supported by the Provence Alpes Côte d'Azur Region for fundings, Météo France for rainfall and altitude data, International Atomic Energy Agency (IAEA) for tritium concentrations data in rains, and Banque HYDRO (MEEDDAT/DGPR/SRNH) for hydrological data.

\section{References}


Andrie and Merlivat, 1988

C. Andrie, L. Merlivat

Tritium in the western Mediterranean Sea during 1981 Phycemed cruise

Deep Sea Res. Part A, 35 (1988), pp. 247-267

Article

Download PDFView Record in ScopusGoogle Scholar

Aragon, 2011

Y. Aragon

Séries temporelles non stationnaires

Séries temporelles avec R: Méthodes et cas, Springer Paris, Paris (2011), pp. 97-120

CrossRefView Record in ScopusGoogle Scholar

Araguás-Araguás and Diaz Teijeiro, 2005

L. Araguás-Araguás, M. Diaz Teijeiro

Isotope composition of precipitation and water vapour in the Iberian Peninsula: first results of the Spanish Network of Isotopes in Precipitation

International Atomic Energy Agency Technical Report, vol. 1453 (2005), pp. 173-190

View Record in ScopusGoogle Scholar

Bailly du Bois et al., 2002

P. Bailly du Bois, P. Germain, M. Rozet, L. Solier

Water masses circulation and residence time in the Celtic Sea and English

Channel approaches, characterisation based on radionuclides labelling from

industrial releases

Proc. International Conference on Radioactivity in Environment (2002), pp. 395-399

Google Scholar

Bates et al., 2015

D. Bates, M. Mächler, B. Bolker, S. Walker

Fitting linear mixed-effects models using Ime4

J. Stat. Softw., 67 (2015), pp. 1-48

View Record in ScopusGoogle Scholar

Bethke and Johnson, 2008

C.M. Bethke, T.M. Johnson

Groundwater age and groundwater age dating

Annu. Rev. Earth Planet. Sci., 36 (2008), pp. 121-152

CrossRefView Record in ScopusGoogle Scholar

Bhattacharya et al., 2003

S.K. Bhattacharya, K. Froehlich, P.K. Aggarwal, K.M. Kulkarni

Isotopic variation in Indian Monsoon precipitation: records from Bombay and New Delhi

Geophys. Res. Lett., 30 (2003)

(n/a-n/a)

Google Scholar

Bondareva and Rubailo, 2016

L.G. Bondareva, A.I. Rubailo

New data on the level of contamination with tritium aerosol fallout in the nearest influence zone of the mining-chemical combine of the Rosatom State

Corporation

Dokl. Earth Sci., 467 (2016), pp. 255-258

View Record in ScopusGoogle Scholar

Bourrin et al., 2006

F. Bourrin, X. Durrieu De Madron, W. Ludwig 
Contribution to the study of coastal rivers and associated prodeltas to sediment supply in the Gulf of Lions (NW Mediterranean Sea)

Vie et milieu - Life and Environment, 56 (2006), pp. 307-314

View Record in ScopusGoogle Scholar

Broecker et al., 1986

W. Broecker, T. Peng, G. Ostlund

Distribution of bomb tritium in the ocean

J. Geophys. Res., 91 (1986), pp. 14,331-14,344

Google Scholar

Bush, 1988

K.A. Bush

Identification of Savannah river water on the South Atlantic Bight shelf using tritium

J. Geophys. Res. Oceans, 93 (1988), pp. 9315-9331

View Record in ScopusGoogle Scholar

Butzin and Roether, 2004

M. Butzin, W. Roether

Tritium budget of the South Atlantic

J. Geophys. Res. Oceans, 109 (2004)

Google Scholar

Cartwright and Morgenstern, 2015

I. Cartwright, U. Morgenstern

Transit times from rainfall to baseflow in headwater catchments estimated using tritium: the Ovens River, Australia

Hydrol. Earth Syst. Sci., 19 (2015), pp. 3771-3785

CrossRefView Record in ScopusGoogle Scholar

Cauquoin et al., 2015

A. Cauquoin, P. Jean-Baptiste, C. Risi, É. Fourré, B. Stenni, A. Landais

The global distribution of natural tritium in precipitation simulated with an

Atmospheric General Circulation Model and comparison with observations

Earth Planet. Sci. Lett., 427 (2015), pp. 160-170

Article

Download PDFView Record in ScopusGoogle Scholar

Ciffroy et al., 2006

P. Ciffroy, F. Siclet, C. Damois, M. Luck

A dynamic model for assessing radiological consequences of tritium routinely released in rivers. Application to the Loire River

J. Environ. Radioact., 90 (2006), pp. 110-139

$\underline{\text { Article }}$

Download PDFView Record in ScopusGoogle Scholar

Craig and Lal, 1961

H. Craig, D. Lal

The production rate of natural tritium

Tellus, 13 (1961), pp. 85-105

CrossRefView Record in ScopusGoogle Scholar

Croudace et al., 2012

I.W. Croudace, P.E. Warwick, J.E. Morris

Evidence for the preservation of technogenic tritiated organic compounds in an estuarine sedimentary environment

Environ. Sci. Technol., 46 (2012), pp. 5704-5712 
CrossRefView Record in ScopusGoogle Scholar

Dinçer and Davis, 1984

T. Dinçer, G. Davis

Application of environmental isotope tracers to modeling in hydrology

J. Hydrol., 68 (1984), pp. 95-113

Article

Download PDFView Record in ScopusGoogle Scholar

Eastoe et al., 2012

C. Eastoe, C. Watts, M. Ploughe, W. Wright

Future use of tritium in mapping pre-bomb groundwater volumes

Ground Water, 50 (2012), pp. 87-93

Ehhalt, 1971

CrossRefView Record in ScopusGoogle Scholar

D. Ehhalt

Vertical profiles and transport of HTO in the troposphere

J. Geophys. Res., 76 (1971), pp. 7351-7367

View Record in ScopusGoogle Scholar

Eisenbud et al., 1979

M. Eisenbud, B. Bennett, R. Blanco

Tritium in the environment

NCRP Report No. 62. Behaviour of Tritium in the Environment (1979)

Google Scholar

El-Kharbachi et al., 2014

A. El-Kharbachi, J. Chêne, S. Garcia-Argote, L. Marchetti, F. Martin, F. Miserque, et al.

Tritium absorption/desorption in ITER-like tungsten particles

Int. J. Hydrog. Energy, 39 (2014), pp. 10525-10536

$\underline{\text { Article }}$

Download PDFView Record in ScopusGoogle Scholar

Eyrolle-Boyer et al., 2014

F. Eyrolle-Boyer, P. Boyer, D. Claval, S. Charmasson, C. Cossonnet

Apparent enrichment of organically bound tritium in rivers explained by the heritage of our past

J. Environ. Radioact., 136 (2014), pp. 162-168

Article

Download PDFView Record in ScopusGoogle Scholar

Eyrolle-Boyer et al., 2015

F. Eyrolle-Boyer, C. Antonelli, P. Renaud, D. Tournieux

Origins and trend of radionuclides within the lower Rhône River over the last

decades

Radioprotection, 50 (2015), pp. 27-34

CrossRefView Record in ScopusGoogle Scholar

Gleeson et al., 2016

T. Gleeson, K.M. Befus, S. Jasechko, E. Luijendijk, M.B. Cardenas

The global volume and distribution of modern groundwater

Nat. Geosci., 9 (2016), pp. 161-167

CrossRefGoogle Scholar

Gontier and Siclet, 2011

G. Gontier, F. Siclet 
Organic tritium in freshwater ecosystems: long-term trends in the environment of French nuclear power plants

Radioprotection, 46 (2011), pp. 457-491

CrossRefView Record in ScopusGoogle Scholar

Göte Östlund, 1994

H. Göte Östlund

Isotope tracing of Siberian river water in the Arctic Ocean

J. Environ. Radioact., 25 (1994), pp. 57-63

Google Scholar

Göte Östlund et al., 1974

H. Göte Östlund, H. Gorman Dorsey, C.G. Rooth

Geosecs North Atlantic radiocarbon and tritium results

Earth Planet. Sci. Lett., 23 (1974), pp. 69-86

$\underline{\text { Article }}$

Download PDFView Record in ScopusGoogle Scholar

Gusyev et al., 2013

M. Gusyev, M. Toews, U. Morgenstern, M. Stewart, P. White, C. Daughney, et al.

Calibration of a transient transport model to tritium data in streams and simulation of groundwater ages in the western Lake Taupo catchment, New

Zealand

Hydrol. Earth Syst. Sci., 17 (2013), p. 1217

CrossRefView Record in ScopusGoogle Scholar

Gusyev et al., 2016

M.A. Gusyev, U. Morgenstern, M.K. Stewart, Y. Yamazaki, K. Kashiwaya, T.

Nishihara, et al.

Application of tritium in precipitation and river water in Japan: a case study of groundwater transit times and storage in Hokkaido watersheds

Hydrol. Earth Syst. Sci. (2016)

Google Scholar

Hadžišehović et al., 1978

M. Hadžišehović, A. Milojević, K. Buraei, M. Ristić, N. Tončev, D. Spasova, et al.

Determination of tritium in natural waters

J. Radioanal. Chem., 44 (1978), pp. 301-306

View Record in ScopusGoogle Scholar

Hadžišehović et al., 1982

M. Hadžišehović, D. Spasova, A. Milojević, K. Buraei, M. Župancić, V. Urosević, et al.

Characteristics of the tritium distribution in the Danube basin region in

Yugoslavia

J. Radioanal. Chem., 74 (1982), pp. 239-248

View Record in ScopusGoogle Scholar

Halder et al., 2015

J. Halder, S. Terzer, L.I. Wassenaar, L.J. Araguás-Araguás, P.K. Aggarwal

The Global Network of Isotopes in Rivers (GNIR): integration of water isotopes in watershed observation and riverine research

Hydrol. Earth Syst. Sci., 19 (2015), pp. 3419-3431

CrossRefView Record in ScopusGoogle Scholar

$\underline{\text { Harms et al., } 2016}$

P.A. Harms, A. Visser, J.E. Moran, B.K. Esser

Distribution of tritium in precipitation and surface water in California 
J. Hydrol., 534 (2016), pp. 63-72

Article

Download PDFView Record in ScopusGoogle Scholar

Hayashi et al., 1999

Y. Hayashi, N. Momoshima, Y. Maeda, H. Kakiuchi

Relation between tritium concentration and chemical composition in rain at

Fukuoka

J. Radioanal. Nucl. Chem., 239 (1999), pp. 517-522

View Record in ScopusGoogle Scholar

Hothorn et al., 2008

T. Hothorn, F. Bretz, P. Westfall

Simultaneous inference in general parametric models

Biom. J., 50 (2008), pp. 346-363

CrossRefView Record in ScopusGoogle Scholar

Hyndman, 2016

R.J. Hyndman

forecast: Forecasting Functions for Time Series and Linear Models

(2016)

Google Scholar

$\underline{\text { IRSN, } 2009}$

IRSN

Le tritium dans l'environnement - Synthèse des connaissances

2009-05 RD, Institut de Radioprotection et de Sûreté Nucléaire (IRSN) (2009), p. 126

View Record in ScopusGoogle Scholar

Jordan et al., 2003

C. Jordan, J.E. Dibb, R. Finkel

$10 \mathrm{Be} / 7 \mathrm{Be}$ tracer of atmospheric transport and stratosphere-troposphere

exchange

J. Geophys. Res. Atmos., 108 (2003)

Google Scholar

Jouzel et al., 1977

J. Jouzel, L. Merlivat, M. Pourchet

Deuterium, tritium, and $\beta$ activity in a snow core taken on the summit of Mont

Blanc (French Alps). Determination of the accumulation rate

J. Glaciol., 18 (1977), pp. 465-470

View Record in ScopusGoogle Scholar

Kakiuchi et al., 2012

H. Kakiuchi, N. Akata, H. Hasegawa, S. Ueda, S. Tokonami, M. Yamada, et al.

Concentration of $\mathbf{3 H}$ in plants around Fukushima Dai-ichi nuclear power station

Sci. Report. Nat., 2 (2012), p. 947

View Record in ScopusGoogle Scholar

Kazemi et al., 2006

G. Kazemi, J. Lehr, P. Perrochet

Groundwater Age

Wiley-Interscience, Hoboken, New Jersey (2006)

(325 pp)

Google Scholar

Kotzer and Workman, 1999

T.G. Kotzer, W. Workman 
Measurements of Tritium (HTO, TFWT, OBT) in Environmental Samples at Varying Distances From a Nuclear Generating Station

Environmental Technologies Branch, Chalk River Laboratories

(1999)

Google Scholar

Krejci and Zeller, 1979

K. Krejci, A. Zeller Jr.

Tritium pollution in the Swiss luminous compound industry

Behaviour of Tritium in the Environment (1979), pp. 65-77

View Record in ScopusGoogle Scholar

Lionello et al., 2006

P. Lionello, P. Malanotte-Rizzoli, R. Boscolo

Mediterranean Climate Variability

vol. 4, Elsevier (2006)

Google Scholar

Marang et al., 2011

L. Marang, F. Siclet, M. Luck, D. Maro, L. Tenailleau, P. Jean-Baptiste, et al.

Modelling tritium flux from water to atmosphere: application to the Loire River

J. Environ. Radioact., 102 (2011), pp. 244-251

$\underline{\text { Article }}$

Download PDFView Record in ScopusGoogle Scholar

Marion, 2010

C. Marion

Dynamique et bilans des transferts particulaires de radioéléments d'origine anthropique et naturelle dans le Golfe du Lion: cas particulier des apports rhodaniens

Université de Perpignan Via Domitia (2010)

Google Scholar

Matsumoto et al., 2013

T. Matsumoto, T. Maruoka, G. Shimoda, H. Obata, H. Kagi, K. Suzuki, et al.

Tritium in Japanese precipitation following the March 2011 Fukushima Daiichi nuclear plant accident

Sci. Total Environ., 445 (2013), pp. 365-370

Article

Download PDFView Record in ScopusGoogle Scholar

Mayer et al., 2014

A. Mayer, J. Sültenfuß, Y. Travi, R. Rebeix, R. Purtschert, C. Claude, et al.

A multi-tracer study of groundwater origin and transit-time in the aquifers of the Venice region (Italy)

Appl. Geochem., 50 (2014), pp. 177-198

Article

Download PDFView Record in ScopusGoogle Scholar

Michel, 1992

R.L. Michel

Residence times in river basins as determined by analysis of long-term tritium records

J. Hydrol., 130 (1992), pp. 367-378

Article

Download PDFView Record in ScopusGoogle Scholar

Michel, 2004 
R.L. Michel

Tritium hydrology of the Mississippi River basin

Hydrol. Process., 18 (2004), pp. 1255-1269

View Record in ScopusGoogle Scholar

Michel et al., 2013

R. Michel, P. Aggarwal, L. Araguas Araguas, B. Newman, T. Kurttas

Use of isotopic data to determine influence of seasonal effects in rivers

Isotopes in Hydrology, Marine Ecosystems and Climate Change Studies. Vol. I.

Proceedings of an International Symposium (2013)

Google Scholar

Mitchell et al., 2008

P.I. Mitchell, L.L. Vintró, J.G. Howlett, M. Burkitbayev, N.D. Priest, Y.G. Strilchuk

Tritium in streams, well waters and atomic lakes at the Semi-Palatinsk Nuclear

Test Site: present status and future perspectives

B. Salbu, L. Skipperud (Eds.), Nuclear Risks in Central Asia, Springer Netherlands,

Dordrecht (2008), pp. 41-60

CrossRefGoogle Scholar

Momoshima et al., 1991

N. Momoshima, T. Kaji, I.T. Poppy, N. Inoue, Y. Takashima

Tritium concentrations of river water on northern and southern islands of Japan

J. Radioanal. Nucl. Chem., 150 (1991), pp. 163-169

View Record in ScopusGoogle Scholar

Mundschenk and Krause, 1991

H. Mundschenk, W.J. Krause

Behaviour and radiological significance of tritium from nuclear power plants and other sources in the Rhine River basin

J. Environ. Radioact., 14 (1991), pp. 341-360

Article

Download PDFView Record in ScopusGoogle Scholar

$\underline{\text { Newell, } 1963}$

R.E. Newell

Transfer through the tropopause and within the stratosphere

Q. J. R. Meteorol. Soc., 89 (1963), pp. 167-204

CrossRefView Record in ScopusGoogle Scholar

$\underline{\text { Okai et al., } 1999}$

T. Okai, N. Momoshima, Y. Takashima

Variation of atmospheric tritium concentrations in three different chemical

forms in Fukuoka, Japan

J. Radioanal. Nucl. Chem., 239 (1999), pp. 527-531

View Record in ScopusGoogle Scholar

Pedro et al., 2011

J. Pedro, U. Heikkilä, A. Klekociuk, A. Smith, T. Ommen, M. Curran

Beryllium-10 transport to Antarctica: results from seasonally resolved observations and modeling

J. Geophys. Res. Atmos., 116 (2011)

Google Scholar

Péron et al., 2016

O. Péron, C. Gégout, B. Reeves, G. Rousseau, G. Montavon, C. Landesman

Anthropogenic tritium in the Loire River estuary, France

J. Sea Res., 118 (2016), pp. 69-76 
$\underline{\text { Article }}$

Download PDFView Record in ScopusGoogle Scholar

Povinec et al., 2017

P. Povinec, L.L.W. Kwong, J. Kaizer, M. Molnár, H. Nies, L. Palcsu, et al.

Impact of the Fukushima accident on tritium, radiocarbon and radiocesium levels in seawater of the western North Pacific Ocean: a comparison with preFukushima situation

J. Environ. Radioact., 166 (2017), pp. 56-66

Article

Download PDFView Record in ScopusGoogle Scholar

Pujol and Sanchez-Cabeza, 2000

L. Pujol, J.A. Sanchez-Cabeza

Natural and artificial radioactivity in surface waters of the Ebro river basin (Northeast Spain)

J. Environ. Radioact., 51 (2000), pp. 181-210

Article

Download PDFView Record in ScopusGoogle Scholar

$\underline{\text { R StudioTeam, } 2015}$

R StudioTeam

RStudio: Integrated Development for $\mathbf{R}$

RStudio, Inc., Boston, MA (2015)

Google Scholar

Radwan et al., 2001

I. Radwan, Z. Pietrzak-Flis, T. Wardaszko

Tritium in surface waters, tap water and in precipitation in Poland during the 1994-1999 period

J. Radioanal. Nucl. Chem., 247 (2001), pp. 71-77

View Record in ScopusGoogle Scholar

$\underline{\text { Rank et al., } 1998}$

D. Rank, A. Adler, L. Araguás Araguás, K. Froehlich, K. Rozanski, W. Stichler

Hydrological parameters and climatic signals derived from long-term tritium and stable isotope time series of the River Danube

Isotope Techniques in the Study of Environmental Change (1998), pp. 191-205

View Record in ScopusGoogle Scholar

Ravikumar and Somashekar, 2011

P. Ravikumar, R.K. Somashekar

Environmental tritium (3H) and hydrochemical investigations to evaluate groundwater in Varahi and Markandeya river basins, Karnataka, India

J. Environ. Radioact., 102 (2011), pp. 153-162

Article

Download PDFView Record in ScopusGoogle Scholar

$\underline{\text { Roether, } 1968}$

W. Roether

Estimating the Tritium Input to Groundwater From Wine Samples:

Groundwater and Direct Run-off Contribution to Central European Surface

Waters

Heidelberg Univ (1968)

Google Scholar

Rozanski et al., 1991

K. Rozanski, R. Gonfiantini, L. Araguasaraguas 
Tritium in the global atmosphere - distribution patterns and recent trends

J. Phys. G: Nucl. Part. Phys., 17 (1991), pp. S523-S536

View Record in ScopusGoogle Scholar

Solder et al., 2016

J.E. Solder, B.J. Stolp, V.M. Heilweil, D.D. Susong

Characterization of mean transit time at large springs in the Upper Colorado

River Basin, USA: a tool for assessing groundwater discharge vulnerability

Hydrogeol. J., 24 (2016), pp. 2017-2033

CrossRefView Record in ScopusGoogle Scholar

Stewart and Farnsworth, 1968

G. Stewart, R. Farnsworth

United States tritium rainout and its hydrologie implications

Water Resour. Res., 4 (1968), pp. 273-289

View Record in ScopusGoogle Scholar

Subbotin et al., 2013

S.B. Subbotin, A.O. Aidarkhanov, Y.V. Dubasov

Migration of tritium with underground waters on the former Semipalatinsk test site

Radiochemistry, 55 (2013), pp. 557-565

View Record in ScopusGoogle Scholar

Tadros et al., 2014

C.V. Tadros, C.E. Hughes, J. Crawford, S.E. Hollins, R. Chisari

Tritium in Australian precipitation: a 50 year record

J. Hydrol., 513 (2014), pp. 262-273

Article

Download PDFView Record in ScopusGoogle Scholar

$\underline{\text { Team RC, } 2016}$

Team RC

R: A Language and Environment for Statistical Computing

R Foundation for Statistical Computing, Vienna, Austria (2016)

URL

http://www.R-project.org

(2015)

Google Scholar

Tomášek and Wilhelmová, 1996

M. Tomášek, L. Wilhelmová

Tritium volume activity in natural waters of the NPP Temelín region

J. Radioanal. Nucl. Chem., 209 (1996), pp. 387-390

View Record in ScopusGoogle Scholar

Tonosaki et al., 2000

K. Tonosaki, H. Kudoh, H. Kimura

Tritium concentrations of natural waters in Rokkasho-Mura

J. Radioanal. Nucl. Chem., 243 (2000), pp. 579-585

View Record in ScopusGoogle Scholar

Ueda et al., 2015

S. Ueda, H. Hasegawa, H. Kakiuchi, S. Ochiai, N. Akata, Hisamatsu Si

Nuclear accident-derived $3 \mathrm{H}$ in river water of Fukushima Prefecture during

2011-2014

J. Environ. Radioact., 146 (2015), pp. 102-109

$\underline{\text { Article }}$ 
Download PDFView Record in ScopusGoogle Scholar

Uhlenbrook et al., 2002

S. Uhlenbrook, M. Frey, C. Leibundgut, P. Maloszewski

Hydrograph separations in a mesoscale mountainous basin at event and seasonal timescales

Water Resour. Res., 38 (2002)

Google Scholar

UNSCEAR, 2000

UNSCEAR

Sources and effects of ionizing radiation

Exposures to the Public From Man-made Sources of Radiation, Annexe C, Comité scientifique des Nations Unies pour l'étude des effets des rayonnements ionisants 1 -

Sources, UNSCEAR (2000), p. 134

Google Scholar

Vakulovskii et al., 1978

S.M. Vakulovskii, A.I. Vorontsov, I.Y. Katrich, I.A. Koloskov, F.Y. Rovinskii, E.I. Roslyi

Tritium in atmospheric precipitations, rivers, and the seas in and around the USSR territory

Sov. At. Energy, 44 (1978), pp. 497-501

View Record in ScopusGoogle Scholar

Varlam et al., 2012

C. Varlam, I. Stefanescu, A. Soare, I. Faurescu

Tritium concentration in different European surface waters

21st International Conference Nuclear Energy for New Europe (2012), pp. 5-7

(September)

View Record in ScopusGoogle Scholar

Ward and Robinson, 1967

R.C. Ward, M. Robinson

Principles of Hydrology

McGraw-Hill, New York (1967)

Google Scholar

$\underline{\text { Weiss et al., } 1979}$

W. Weiss, J. Bullacher, W. Roether

Evidence of pulsed discharges of tritium from nuclear energy installations in

Central European precipitation

Behaviour of Tritium in the Environment (1979)

Google Scholar

Zerriffi, 1996

H. Zerriffi

Tritium: The Environmental, Health, Budgetary, and Strategic Effects of the

Department of Energy's Decision to Produce Tritium

IEER (1996)

(January)

Google Scholar

Zuur et al., 2009a

A.F. Zuur, E.N. Ieno, N.J. Walker, A.A. Saveliev, G.M. Smith

Violation of Independence-Part II. Mixed Effects Models and Extensions in Ecology With R

Springer (2009), pp. 161-191 
CrossRefView Record in ScopusGoogle Scholar

Zuur et al., 2009b

A.F. Zuur, E.N. Ieno, N.J. Walker, A.A. Saveliev, G.M. Smith

Violation of Independence - Part I. Mixed Effects Models and Extensions in Ecology With R

Springer New York, New York, NY (2009), pp. 143-160

CrossRefGoogle Scholar 